\title{
Iron cycling and nutrient-limitation patterns in surface waters of the World Ocean
}

\author{
J. Keith Moore ${ }^{\mathrm{a}, *}$, Scott C. Doney, David M. Glover ${ }^{\mathrm{b}}$, Inez Y. Fung \\ ${ }^{a}$ National Center for Atmospheric Research NCAR, P.O. Box 3000, Boulder, CO 80307, USA \\ ${ }^{\mathrm{b}}$ Woods Hole Oceanographic Institution, 573 Woods Hole Road, Woods Hole, MA 02543, USA \\ ${ }^{\mathrm{c}}$ University of California Berkeley, 301 McCone Hall, Berkeley, CA 94720, USA
}

Accepted 17 June 2001

\begin{abstract}
A global marine ecosystem mixed-layer model is used to study iron cycling and nutrient-limitation patterns in surface waters of the world ocean. The ecosystem model has a small phytoplankton size class whose growth can be limited by N, P, Fe, and/or light, a diatom class which can also be Si-limited, and a diazotroph phytoplankton class whose growth rates can be limited by $\mathrm{P}, \mathrm{Fe}$, and/or light levels. The model also includes a parameterization of calcification by phytoplankton and is described in detail by Moore et al. (Deep-Sea Res. II, 2002).

The model reproduces the observed high nitrate, low chlorophyll (HNLC) conditions in the Southern Ocean, subarctic Northeast Pacific, and equatorial Pacific, and realistic global patterns of primary production, biogenic silica production, nitrogen fixation, particulate organic carbon export, calcium carbonate export, and surface chlorophyll concentrations. Phytoplankton cellular $\mathrm{Fe} / \mathrm{C}$ ratios and surface layer dissolved iron concentrations are also in general agreement with the limited field data. Primary production, community structure, and the sinking carbon flux are quite sensitive to large variations in the atmospheric iron source, particularly in the HNLC regions, supporting the Iron Hypothesis of Martin (Paleoceanography 5 (1990) 1-13). Nitrogen fixation is also strongly influenced by atmospheric iron deposition.

Nitrogen limits phytoplankton growth rates over less than half of the world ocean during summer months. Export of biogenic carbon is dominated by the sinking particulate flux, but detrainment and turbulent mixing account for $30 \%$ of global carbon export. Our results, in conjunction with other recent studies, suggest the familiar paradigm that nitrate inputs to the surface layer can be equated with particulate carbon export needs to be expanded to include multiple limiting nutrients and modes of export. (C) 2001 Elsevier Science Ltd. All rights reserved.
\end{abstract}

\footnotetext{
*Corresponding author.

E-mail address: jkmoore@ucar.edu (J.K. Moore).
} 


\section{Introduction}

In recent years the micronutrient iron has been shown to play a key role in limiting phytoplankton growth rates and structuring plankton communities over much of the world ocean, particularly in the high nitrate, low chlorophyll (HNLC) regions (Martin et al., 1989, 1990, 1991; Martin, 1992; Helbling et al., 1991; Price et al., 1994; Takeda and Obata, 1995; de Baar et al., 1995; Coale et al., 1996; Landry et al., 1997; Takeda, 1998; Behrenfeld and Kolber, 1999; Boyd and Harrison, 1999; Moore et al., 2000). In a companion paper (Moore et al., 2002, hereafter referred to as MET) we describe a new marine ecosystem model (modified from the model of Doney et al., 1996, to allow for multiple nutrient limitation, three phytoplankton classes and iron cycling) and compare model output with field data from nine JGOFS sites. These sites include a wide variety of ecosystem types and physical forcings. The model reproduces seasonal patterns in ambient nutrient concentrations, phytoplankton biomass, primary and export production, nitrogen fixation, and chlorophyll concentrations at these diverse locations (MET). Here we use the ecosystem model to examine iron cycling and nutrient-limitation patterns in the surface mixed layer at the global scale.

The ecosystem model has three classes of phytoplankton: a small size class whose growth can be limited by N, P, Fe, and/or light levels; a larger size class (explicitly modeled as diatoms) whose growth rates can be limited by $\mathrm{N}, \mathrm{P}, \mathrm{Fe}, \mathrm{Si}$, and/or light; and a third class of nitrogen-fixing phytoplankton (diazotrophs) than can be limited by $\mathrm{P}, \mathrm{Fe}$, and/or light (see MET). Cell quotas of each nutrient are computed relative to carbon, and maximum and minimum cell quotas for each nutrient are inputs to the model, based on Geider et al. (1998). The small phytoplankton have lower half-saturation constants for nutrient uptake and experience stronger grazing pressure than the diatoms (MET). Nutrient uptake half-saturation constants for the diazotrophs are intermediate and the grazing pressure is low (see MET). Production by diatoms is largely routed to the sinking detrital pool, while production by the small phytoplankton and diazotrophs mainly ends up in the non-sinking detrital pool (MET). Phytoplankton adapt dynamically to changing light and nutrient conditions in the manner of the model of Geider et al. (1998), which has been modified to allow for multiple limiting nutrients. Thus, $\mathrm{N} / \mathrm{C}, \mathrm{Fe} / \mathrm{C}, \mathrm{Si} / \mathrm{C}, \mathrm{P} / \mathrm{C}$, and $\mathrm{Chl} / \mathrm{C}$ ratios all are variable and adjust dynamically to changing environmental conditions (MET). Photoadaptation is according to Geider et al. (1996, 1998).

Both laboratory and fieldwork have shown considerable variability in $\mathrm{Fe} / \mathrm{C}$ ratios of phytoplankton as a function of Fe availability (Sunda et al., 1991; Sunda and Huntsman, 1995, 1997; Sunda, 1997). Sunda (1997) used profiles of dissolved iron and apparent oxygen utilization from the Moss Landing database (Johnson et al., 1997) to estimate the $\mathrm{Fe} / \mathrm{C}$ ratios of sinking particulate matter. Strongly Fe-limited regions such as the equatorial Pacific and the Southern Ocean had $\mathrm{Fe} / \mathrm{C}$ ratios of $\sim 2 \mu \mathrm{mol} / \mathrm{mol}$, while more Fe-replete areas such as the North Atlantic had significantly higher ratios $(>7 \mu \mathrm{mol} / \mathrm{mol})$. The low $\mathrm{Fe} / \mathrm{C}$ ratios estimated for the Southern Ocean and equatorial Pacific regions are consistent with the low ratios seen under strong $\mathrm{Fe}$ limitation in culture studies (Sunda and Huntsman, 1995, 1997).

Estimates of oceanic iron deposition to the oceans via mineral dust vary considerably. Duce and Tindale (1991) estimated total iron flux to the oceans of $3.2 \times 10^{13} \mathrm{~g} \mathrm{Fe} / \mathrm{yr}$ (or $5.7 \times 10^{11} \mathrm{~mol}$ $\mathrm{Fe} / \mathrm{yr}$ ) based on a sparse network of field measurements and an assumed iron content of $3.5 \%$ by weight. Rea (1994) suggested that the dust deposition estimates to the open ocean of Duce et al. 
(1991) (on which the iron deposition estimate of Duce and Tindale (1991) was based) were too high by a factor of $\sim 5$ based on an analysis of marine sediment cores. Fung et al. (2000) estimated iron flux to the global ocean of $1.2 \times 10^{11} \mathrm{~mol} \mathrm{Fe} / \mathrm{yr}$ based on model estimates of dust transport and deposition (Tegen and Fung, 1995) with different assumptions about iron content. Duce and Tindale (1991) included deposition by large particulates that are not transported over long distances and thus are deposited in coastal areas. These large particulates were not included in Tegen and Fung (1995), which partially accounts for the difference in total flux estimates. Mahowald et al. (1999) modeled dust transport and deposition for modern and last glacial maximum (LGM) times. Global spatial patterns of dust/iron deposition to the oceans in Duce and Tindale (1991), Tegen and Fung (1994, 1995) and Mahowald et al. (1999) are all similar, with the largest deposition rates near desert source regions.

There are also uncertainties in the percentage of the iron in dust that is soluble upon entering the ocean. Early studies suggested fairly high solubilities in excess of $10 \%$ (up to $50 \%$ ) (Duce and Tindale, 1991, and references therein). More recent studies suggest lower solubilities (Fung et al., 2000, and references therein). In a recent review, Jickells and Spokes (in press) suggested mean solubility of iron is at most 2\%. Fung et al. (2000) estimated an iron budget for the upper ocean using solubilities of $1 \%$ and 10\%. Archer and Johnson (2000) implemented an iron cycle within a 3D ocean circulation biogeochemistry model. They varied the solubility of dust flux estimates from several studies to best match observed surface phosphate concentrations. We use the Tegen and Fung (1995) dust deposition with an assumed 2\% solubility to estimate atmospheric inputs to the oceanic dissolved iron pool in our standard model run (as in MET). We also examine the sensitivity of the marine ecosystem to variations in atmospheric input using a range of solubilities and dust flux deposition patterns from Tegen and Fung (1995) and Mahowald et al. (1999).

There are still many uncertainties about iron cycling in ocean surface waters despite the progress of recent years (Wells et al., 1995; Johnson et al., 1997). We make a number of simplifying assumptions in order to include Fe limitation of growth and Fe cycling in our model. We assume that all of the dissolved iron is readily available for uptake by the phytoplankton. In reality most dissolved iron is bound to organic ligands (Rue and Bruland, 1995, 1997), much of which appears to be available to phytoplankton (Rue and Bruland, 1995; Maldonado and Price, 1999). However, there may be differences between phytoplankton groups and different chemical chelators that influence iron uptake rates in situ (Hutchins et al., 1999), and some portion of the dissolved pool may be unavailable to phytoplankton. We assume that particulate iron is unavailable to phytoplankton. However phytoplankton capable of phagotrophy may obtain substantial iron from particulate sources (Maranger et al., 1998). Much in-situ remineralization of $\mathrm{Fe}$ may occur within the low $\mathrm{pH}$ food vacuoles or digestive systems of grazers, rather than through the actions of bacteria (Barbeau et al., 1996). This process also may convert some particulate iron into more bioavailable forms (Barbeau et al., 1996). We assume that a portion of grazed iron is remineralized by this process (MET). Detrital remineralization is parameterized with a simple temperature-dependent first-order rate in our model. There is good evidence that Fe is recycled rapidly in situ, but relatively little is known about rates or controlling processes (Hutchins et al., 1993; Price et al., 1994). In summary there is still considerable uncertainty about iron cycling in the oceans, and undoubtedly the model will need to be updated as our understanding of the marine iron cycle improves. 
Phytoplankton geochemical functional groups are a key missing component in our attempts to model biogeochemical cycling in the oceans at present (Doney, 1999). We have included the diatoms and nitrogen-fixing phytoplankton, two key functional groups, explicitly in our model (MET). We also parameterize calcium carbonate production by phytoplankton (the coccolithophores, another key functional group) as a variable percentage of the primary production by our small phytoplankton group (see MET for details). Inclusion of these key functional groups of phytoplankton is needed to model carbon fluxes in the oceans, air-sea carbon exchange, and to reliably predict how the marine carbon cycle will respond to changing environmental conditions (Doney, 1999).

\section{Methods}

A detailed description of the ecosystem model and physical mixed-layer grid is given in MET. The ecosystem model consists of eleven compartments: small phytoplankton, diatoms, diazotrophs, zooplankton, sinking and non-sinking detrital pools, and the nutrients ammonium, nitrate, phosphate, silicate, and iron. We track multiple elements for the biota and detrital pools (N, C, P, Fe, $\mathrm{Si}, \mathrm{CaCO}_{3}$, and $\mathrm{Chl}$, see MET). All model parameters, initial values, and equations are listed in Appendix I of MET.

The model is run on a global surface mixed-layer grid that corresponds in horizontal resolution to the top layer of the National Center for Atmospheric Research (NCAR) Climate Ocean Model (NCOM) (Large et al., 1997; Gent et al., 1998; Doney et al., 1998, submitted). There is no horizontal circulation or advection in this simplified grid. The ecosystem model is run independently at each grid point with no lateral exchange. Climatological forcings at each grid point include the seasonal cycles in surface shortwave radiation (Bishop and Rossow, 1991; Rossow and Schiffer, 1991), sea-surface temperature (World Ocean Atlas 1998 (WOA98) Conkright et al., 1998), mixed-layer depth (Monterey and Levitus, 1997), percent sea-ice cover (National Snow and Ice Data Center, 2000), vertical velocity at the base of the mixed-layer (from output of the NCAR 3D ocean model), turbulent mixing at the base of the mixed layer $(0.15 \mathrm{~m} /$ day), and atmospheric iron and silicon deposition (see MET for details). All forcings are remapped to the NCAR grid, and a cubic spline curve fit is used to interpolate the monthly forcing data at each time step in the model. Downwelling vertical velocities have no effect on mixed-layer concentrations. Upwelling is assumed to export an equal volume of water laterally that dilutes mixed-layer concentrations of most model compartments. Dissolved iron, nitrate, phosphate, and silicate typically have higher subsurface concentrations than the mixed-layer values and their concentrations thus increase. This lateral export is not tracked in the model (it is not added to adjacent gridpoints) and thus represents a loss term for the mixed layer, typically a small fraction of total losses.

Nitrate, phosphate, and silicate concentrations at the base of the mixed layer are derived from WOA98 (Conkright et al., 1998) as described in MET. Iron concentrations below the mixed layer are estimated from the nitrate data using the regional dissolved iron/nitrate ratios estimated by Fung et al. (2000), modified in some areas (see MET). The model is spun up for two years, and monthly output is saved from a third year. This simple mixed-layer formulation works well in most areas but is deficient in areas where lateral advection is important, notably equatorial regions. 
Atmospheric iron deposition is derived from the dust deposition model studies of Tegen and Fung (1994, 1995, hereafter TF95) and Mahowald et al. (1999, hereafter MAH99). We assume that dust is $3.5 \%$ iron by weight. This is the value used by Duce and Tindale (1991) and is very similar to that measured in mineral dust at Barbados by Zhu et al. (1997). This is a simplification, as the percent iron likely varies with source region and dust type (see Fung et al., 2000). We adopt a uniform $2 \%$ solubility for our standard model run but also examine how varying the soluble fraction from $2 \%$ to $10 \%$ impacts the marine ecosystem.

We model mean surface-layer concentrations for all variables but also make some assumptions about concentrations below the mixed layer. When the mixed-layer is shallow $(25 \mathrm{~m})$ we assume that concentrations just below the mixed-layer of all ecosystem variables (except nitrate, silicate, phosphate, and dissolved iron) are at $75 \%$ of the mixed-layer values. The percentage below the mixed-layer declines linearly with increasing mixed-layer depth to a value of 0 at $100 \mathrm{~m}$ depth. Thus, when the mixed layer is shallow and then deepens, there is some entrainment of biota and detritus until the mixed layer reaches $100 \mathrm{~m}$ depth. The loss of biota from the mixed layer due to turbulent mixing is also smaller when the mixed layer is shallow than if we assumed no biota or detritus below the mixed layer (which is not realistic).

Monthly SeaWiFS surface chlorophyll concentrations (Version 2.0) were obtained from the Goddard Distributed Active Archive Center (McClain et al., 1998) for the period October 1998September 1999. We compare model mixed-layer primary production estimates with satellitebased estimates of total euphotic zone productivity from the Vertically Generalized Production Model (VGPM) of Behrenfeld and Falkowski (1997). The VGPM is run on the NCAR grid using the same irradiance, sea-surface temperature, and sea-ice cover data as the model in addition to the SeaWiFS surface chlorophyll data. The VGPM uses a temperature-dependent function to estimate the local maximum production rate (Behrenfeld and Falkowski, 1997).

\section{Results}

\subsection{Atmospheric iron deposition to the oceans}

Annual iron deposition to the oceans from the model studies are shown in Fig. 1 (note the approximate $\log$ scale of the color bar). Total deposition from the two studies is similar in magnitude at $2.67 \times 10^{11} \mathrm{~mol} \mathrm{Fe} / \mathrm{yr}$ from TF95 and $4.59 \times 10^{11} \mathrm{~mol} \mathrm{Fe} / \mathrm{yr}$ for modern times from MAH99. Fung et al. (2000) estimated total iron deposition to the global ocean at $1.18 \times 10^{11} \mathrm{~mol}$ $\mathrm{Fe} / \mathrm{yr}$ based on TF95 using different assumptions about the iron content of dust types. Most of the increased deposition in our study relative to Fung et al. (2000) would be in high dust flux regions where silt is a significant component of deposition (see Tegen and Fung, 1994). Jickells and Spokes (in press) estimated total iron deposition to the oceans to be $2.5-6.3 \times 10^{11} \mathrm{~mol} \mathrm{Fe} / \mathrm{yr}$.

General spatial patterns in the two maps presented here (as well that of Duce and Tindale, 1991) are similar. Highest deposition rates are near the main source regions in northern Africa, the Arabian Peninsula, eastern Asia, Australia, Patogonia, and southern Africa. However, there are some striking differences particularly in the low dust input regions of the Southern Ocean and equatorial Pacific where the TF95 estimates can be 10 times higher than those of MAH99 (Fig. 1). 


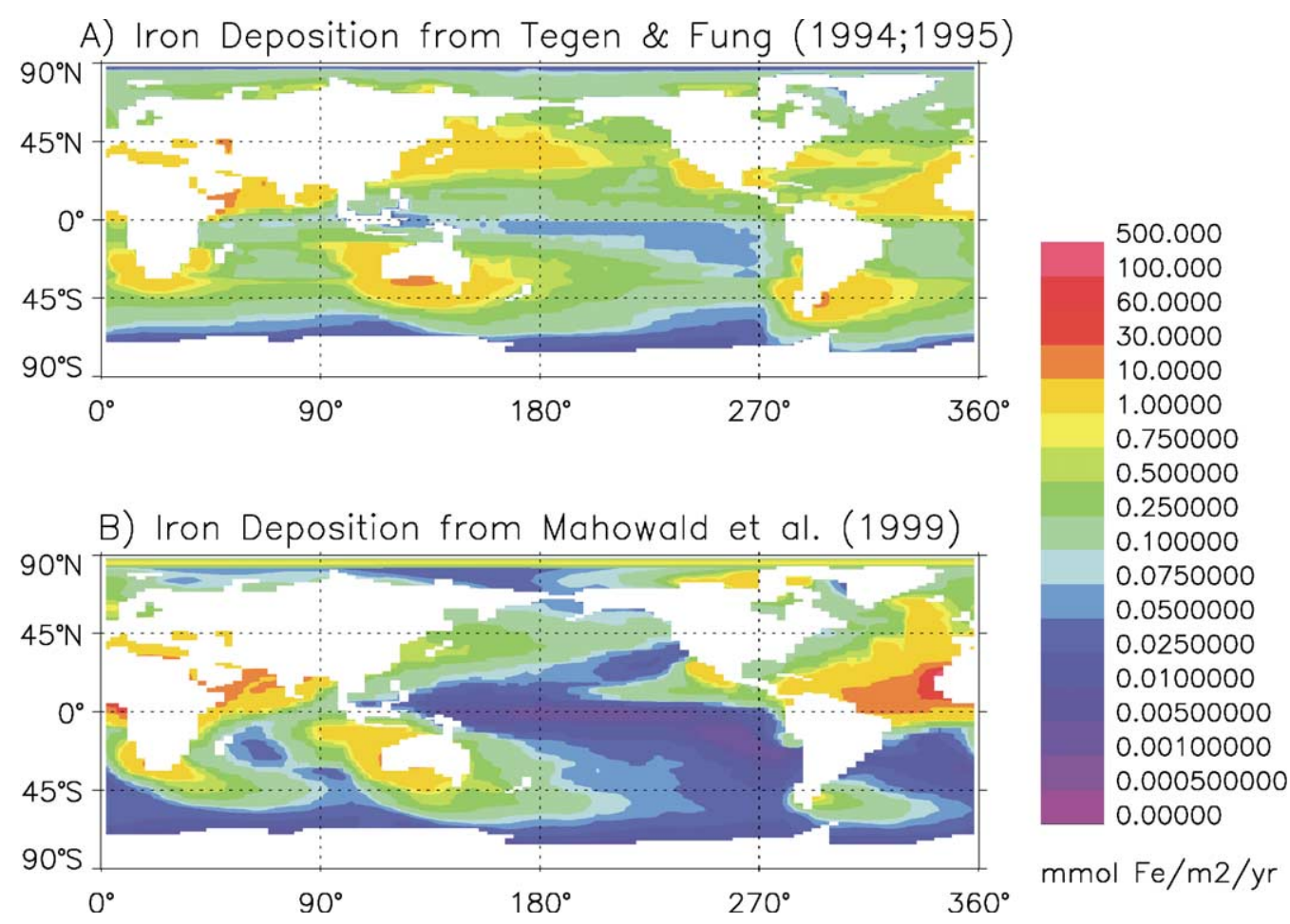

Fig. 1. Annual atmospheric iron input to the oceans estimated from two modeling studies of dust transport and deposition (A) iron deposition from Tegen and Fung (1994, 1995) and (B) Mahowald et al. (1999). Dust was assumed to be $3.5 \%$ iron by weight (see text for details).

In contrast, the deposition near source regions is typically higher in MAH99 than in TF95 (Fig. 1).

A number of factors contribute to the differences in these iron deposition maps. Different definitions of dust source regions and different atmospheric general circulation models were used (with different wind fields, a key factor driving uplift and transport) (TF95; MAH99). TF95 included anthropogenically and climatically disturbed soils as dust sources and suggested these sources could account for up to $50 \%$ of the dust flux from the continents. Both studies suggested the dust flux from Australia was overestimated, and MAH99 noted their dust flux off of Asia in the North Pacific was probably too low.

\subsection{Standard model run}

Mean mixed-layer dissolved iron concentrations from the model for the months of January and July are shown in Fig. 2. Dissolved iron concentrations range from $<15$ to $>2300$ pM. Halfsaturation constants for iron uptake in our model are $200 \mathrm{pM}$ for the diatoms and $80 \mathrm{pM}$ for the small phytoplankton and the diazotrophs (MET). Concentrations are generally low in open-ocean waters during summer $(<100 \mathrm{pM}$, Fig. 2). In the Johnson et al. (1997) database, mean surface concentration was $68 \mathrm{pM}$, but the authors noted this was an overestimate as many samples were 


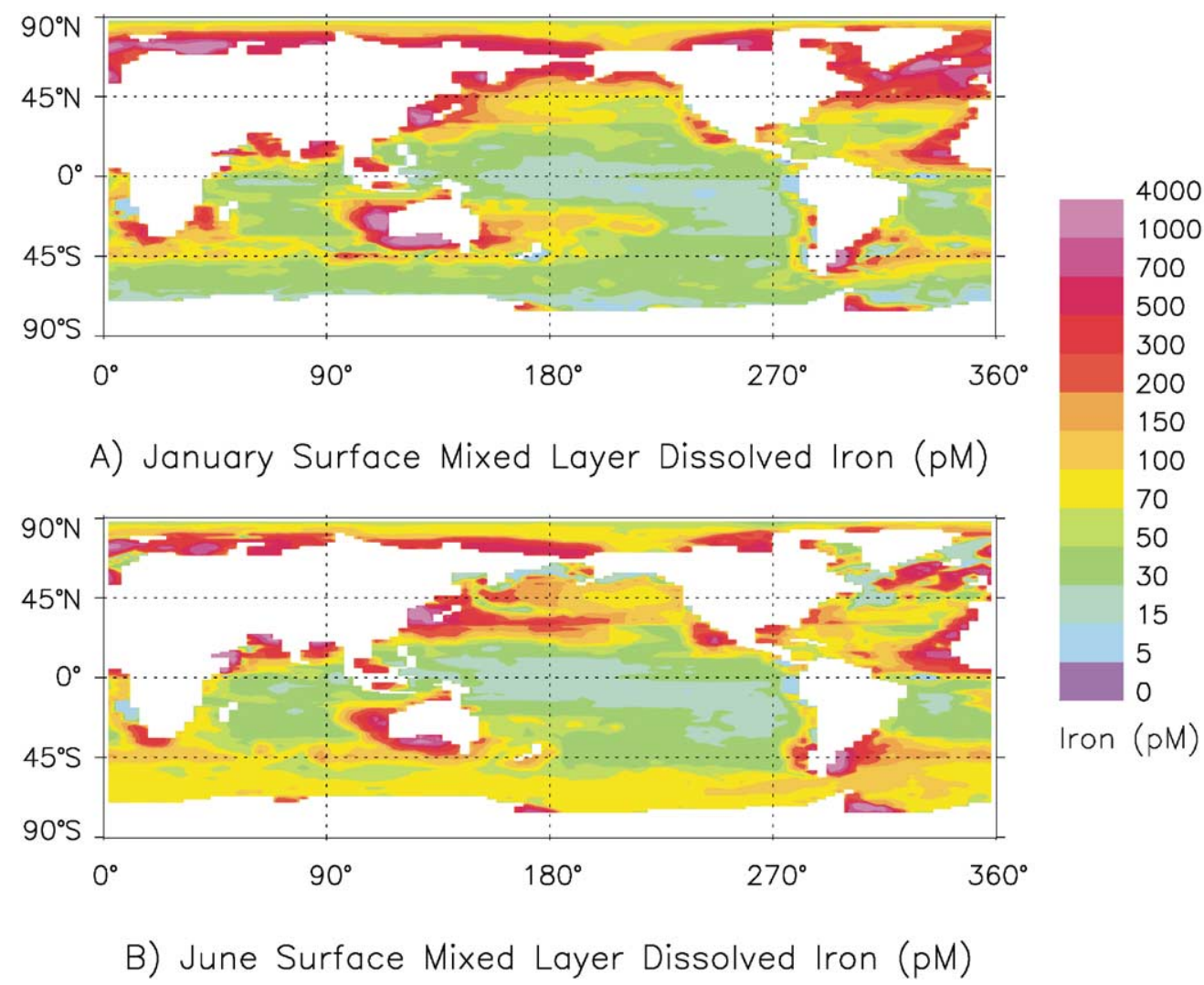

Fig. 2. Model estimates of surface mixed-layer dissolved iron concentrations (pM) for the months of (A) January and (B) July.

below detection limits $(\sim 30 \mathrm{pM})$. In the HNLC regions and parts of the North Atlantic concentrations are $<30 \mathrm{pM}$ during summer, falling below $15 \mathrm{pM}$ in the most iron-stressed regions (Fig. 2). Highest Fe levels are seen in areas of high dust flux (Figs. 1 and 2). It is only in these regions that iron gets much above $1.0 \mathrm{nM}$. Deep winter mixing increases iron levels at high latitudes (Fig. 2), notably in the North Atlantic where winter mixed-layer depths often exceed $500 \mathrm{~m}$.

The elevated iron concentrations in the North Atlantic in January (Fig. 2) are similar to the values measured at depth by Martin et al. (1993) $\left(280 \mathrm{pM}\right.$ at $500 \mathrm{~m}$ and $560 \mathrm{pM}$ at $800 \mathrm{~m}$ at $47^{\circ} \mathrm{N}$, $20^{\circ} \mathrm{W}$, and $360 \mathrm{pM}$ at $600 \mathrm{~m}$ at $59^{\circ} \mathrm{N}, 20^{\circ} \mathrm{W}$ ). Similarly in the western North Atlantic $\mathrm{Wu}$ and Luther (1994) measured dissolved $\mathrm{Fe}$ at $630 \mathrm{pM}$ at $300 \mathrm{~m}$ and $850 \mathrm{pM}$ at $750 \mathrm{~m}$ close to the continental shelf $\left(37.37^{\circ} \mathrm{N}, 73.25^{\circ} \mathrm{W}\right)$ and lower values of $460 \mathrm{pM}$ at $250 \mathrm{~m}$ and $510 \mathrm{pM}$ at $500 \mathrm{~m}$ at a more open ocean station $\left(36.03^{\circ} \mathrm{N}, 72.29^{\circ} \mathrm{W}\right)$. The general agreement between these deep-water measurements and our January mixed-layer concentrations in the North Atlantic indicates that we have adequately estimated subsurface iron concentrations in this region, which required increasing regional values above those used by Fung et al. (2000) (see MET).

Model-predicted dissolved iron concentrations are compared with field measurements of dissolved iron in Table 1. Qualitatively the model predictions are in good agreement with the 
Table 1

Model estimates of surface mixed-layer dissolved iron concentrations are compared with in-situ measurements from selected regions

\begin{tabular}{|c|c|c|c|}
\hline Location & Month & Model iron (pM) & In situ iron $(\mathrm{pM})$ \\
\hline $\begin{array}{l}\text { North Pacific } \\
55.5^{\circ} \mathrm{N}, 147.5^{\circ} \mathrm{W} \\
50^{\circ} \mathrm{N}, 145^{\circ} \mathrm{W} \\
45^{\circ} \mathrm{N}, 143^{\circ} \mathrm{W} \\
35^{\circ} \mathrm{N}, 122^{\circ}-139^{\circ} \mathrm{W} \\
9^{\circ} \mathrm{N}, 147^{\circ} \mathrm{W} \\
22^{\circ} \mathrm{N}, 158^{\circ} \mathrm{W} \\
33^{\circ} \mathrm{N}, 139^{\circ} \mathrm{W} \\
28^{\circ} \mathrm{N}, 158^{\circ} \mathrm{W}\end{array}$ & $\begin{array}{l}\text { August } \\
\text { August } \\
\text { August } \\
\text { June } \\
\text { August } \\
\text { January } \\
\text { July } \\
\text { July }\end{array}$ & $\begin{array}{l}109 \\
83 \\
70 \\
77-157 \\
28 \\
63 \\
120 \\
95\end{array}$ & $\begin{array}{l}68-97^{\mathrm{a}} \\
48-58^{\mathrm{a}} \\
58-78^{\mathrm{a}} \\
48-97^{\mathrm{b}} \\
30^{\mathrm{c}} \\
230^{\mathrm{d}} \\
97^{\mathrm{d}} \\
360^{\mathrm{e}}\end{array}$ \\
\hline $\begin{array}{l}\text { Equatorial Pacific } \\
3^{\circ} \mathrm{S}-9^{\circ} \mathrm{N}, 140^{\circ} \mathrm{W} \\
4-6^{\circ} \mathrm{S}, 105-109^{\circ} \mathrm{W}\end{array}$ & $\begin{array}{l}\text { July } \\
\text { June }\end{array}$ & $\begin{array}{l}22-37 \\
20-23\end{array}$ & $\begin{array}{c}<50^{\mathrm{f}} \\
15-37^{\mathrm{g}}\end{array}$ \\
\hline $\begin{array}{l}\text { North Atlantic } \\
47^{\circ} \mathrm{N}, 20^{\circ} \mathrm{W} \\
59^{\circ} \mathrm{N}, 20^{\circ} \mathrm{W} \\
36^{\circ} \mathrm{N}, 72^{\circ} \mathrm{W}\end{array}$ & $\begin{array}{l}\text { May } \\
\text { May } \\
\text { October }\end{array}$ & $\begin{array}{l}189 \\
151 \\
206\end{array}$ & $\begin{array}{l}68^{\mathrm{h}} \\
78^{\mathrm{h}} \\
75-100^{\mathrm{i}}\end{array}$ \\
\hline $\begin{array}{l}\text { Arabian Sea } \\
10-23^{\circ} \mathrm{N}, 57-69^{\circ} \mathrm{E} \\
10-23^{\circ} \mathrm{N}, 57-69^{\circ} \mathrm{E} \\
10-23^{\circ} \mathrm{N}, 57-69^{\circ} \mathrm{E} \\
10-23^{\circ} \mathrm{N}, 57-69^{\circ} \mathrm{E} \\
10-23^{\circ} \mathrm{N}, 57-69^{\circ} \mathrm{E}\end{array}$ & $\begin{array}{l}\text { January } \\
\text { March } \\
\text { July/August } \\
\text { August/September } \\
\text { November }\end{array}$ & $\begin{array}{l}13-904 \\
8-863 \\
46-6184 \\
28-6184 \\
67-1900\end{array}$ & $\begin{array}{l}480-2380^{j} \\
500-1800^{j} \\
570-2400^{j} \\
480-1670^{j} \\
430-2930^{j}\end{array}$ \\
\hline $\begin{array}{l}\text { Southern Ocean } \\
59-61^{\circ} \mathrm{S}, 170^{\circ} \mathrm{W} \\
53-65^{\circ} \mathrm{S}, 170^{\circ} \mathrm{W} \\
60-68^{\circ} \mathrm{S}, 170^{\circ} \mathrm{W} \\
53-71^{\circ} \mathrm{S}, 170^{\circ} \mathrm{W} \\
50-67^{\circ} \mathrm{S}, \sim 90^{\circ} \mathrm{W} \\
46-60^{\circ} \mathrm{S}, \sim 6^{\circ} \mathrm{W} \\
40^{\circ} \mathrm{S}, 140^{\circ} \mathrm{E} \\
45^{\circ} \mathrm{S}, 140^{\circ} \mathrm{E} \\
50^{\circ} \mathrm{S}, 140^{\circ} \mathrm{E} \\
53^{\circ} \mathrm{S}, 140^{\circ} \mathrm{E} \\
41^{\circ} \mathrm{S}, 143.5^{\circ} \mathrm{E} \\
76.5^{\circ}-74^{\circ} \mathrm{S}, 180-168.5^{\circ} \mathrm{W} \\
76.5-75^{\circ} \mathrm{S}, 182-170^{\circ} \mathrm{W}\end{array}$ & $\begin{array}{l}\text { October/November } \\
\text { December } \\
\text { January/February } \\
\text { February/March } \\
\text { March/April } \\
\text { October/November } \\
\text { January } \\
\text { January } \\
\text { January } \\
\text { January } \\
\text { January } \\
\text { November } \\
\text { December/January }\end{array}$ & $\begin{array}{l}25-90 \\
13-40 \\
17-42 \\
34-75 \\
32-59 \\
17-110 \\
40 \\
104 \\
56 \\
51 \\
172 \\
87-1438 \\
21-1285\end{array}$ & $\begin{array}{l}150-300^{\mathrm{k}} \\
100-300^{\mathrm{k}} \\
90-210^{\mathrm{k}} \\
90-210^{\mathrm{k}} \\
50-200^{\mathrm{l}} \\
40-3000^{\mathrm{m}} \\
310-600^{\mathrm{n}} \\
100-290^{\mathrm{n}} \\
220-280^{\mathrm{n}} \\
200-300^{\mathrm{n}} \\
600-700^{\mathrm{n}} \\
450-3800^{\mathrm{o}} \\
90-225^{\mathrm{o}}\end{array}$ \\
\hline
\end{tabular}

\footnotetext{
${ }^{\mathrm{a}}$ Martin et al. (1989).

${ }^{\mathrm{b}}$ Martin and Gordon (1988).

${ }^{\mathrm{c}}$ DiTullio et al. (1993).

${ }^{\mathrm{d}}$ Rue and Bruland (1995).

${ }^{\mathrm{e}}$ Bruland et al. (1994).

${ }^{\mathrm{f}}$ Gordon et al. (1997).

${ }^{\mathrm{g}}$ Rue and Bruland (1997).

${ }^{\mathrm{h}}$ Martin et al. (1993).

${ }^{\mathrm{i}} \mathrm{Wu}$ and Luther (1996).

${ }^{\mathrm{j}}$ Measures and Vink (1999).

${ }^{\mathrm{k}}$ Measures and Vink (2001).

${ }^{1}$ de Baar et al. (1999).

${ }^{\mathrm{m}}$ Löscher et al. (1997).

${ }^{\mathrm{n}}$ Sedwick et al. (1997).

${ }^{\circ}$ Sedwick et al. (2000).
} 
in-situ measurements. Lowest iron concentrations are seen in the equatorial Pacific and the high latitude Southern Ocean (Fig. 2, Table 1). Higher concentrations are seen in the Arabian and Ross Seas, with intermediate values in the mid-ocean gyres and North Atlantic. Quantitatively model estimates are often lower than the in-situ measurements. There are several of possible reasons for this discrepancy. Measurements of dissolved iron by different researchers can differ by a factor of two or more (MET), with measurements by the Moss Landing group often lower than other groups. For example, none of the surface samples in the Johnson et al. (1997) data set were above 200 pM, while most samples measured by Löscher et al. (1997) were $>200$ pM. The factors driving these differences in iron concentration measurements remain to be resolved. Measures and Vink (2001) suggest a difference in the organic fraction measured in surface waters. Since our subsurface iron field is derived from the Moss Landing database, it is not surprising that our estimates are closer to the low end of observational measurements made by that group. In addition, we are modeling only the bioavailable portion of the dissolved pool; all dissolved iron is assumed to be available for uptake by phytoplankton. It is not clear what portion of the dissolved pool in situ is actually available for phytoplankton uptake. Small particulate, colloidal forms or iron bound to organic ligands may only be partially available to phytoplankton. Additional deficiencies in the model also could account for the differences.

We compare mean nitrate concentrations in surface waters during summer months (DecemberFebruary in the Southern Hemisphere and June-August in the Northern Hemisphere) with summer season surface values from WOA98 in Fig. 3. The model reproduces the generally high nitrate values in the Southern Ocean, the subarctic and equatorial Pacific, and in the North Atlantic seen in the in-situ data. Nitrate is largely depleted in the North Atlantic by the end of the summer season in the model. The mid-ocean gyres have uniformly low nitrate concentrations in the model output, without the mesoscale variability seen in WOA98. In the model output, phytoplankton blooms have largely depleted nitrate in the upwelling region of the Arabian Sea, while high values are seen in the WOA98 (Fig. 3).

We compare model chlorophyll distributions for the months of June and January with SeaWiFS data in Figs. 4 and 5. For the high latitude areas shown in black there are no SeaWiFS data available, while in the model output these areas indicate very low chlorophyll concentrations $\left(<0.01 \mathrm{mg} / \mathrm{m}^{3}\right)$. Patterns in the model output are similar to the satellite estimates, with the lowest chlorophyll concentrations in the mid-ocean gyres and elevated values at high latitudes (Figs. 4 and 5). Iron limitation maintains relatively low chlorophyll concentrations in the HNLC areas of the subarctic Northeast Pacific, the equatorial Pacific, and the Southern Ocean despite available macronutrients (Figs. 3-5, also MET, and following sections). At mid-latitudes $\left(\sim 45^{\circ} \mathrm{S}\right)$ in the Southern Ocean, both the model output and the SeaWiFS data have lower concentrations in the Pacific sector than in other areas (Fig. 4). In the model this pattern is driven by stronger Fe limitation in the Pacific sector due to very low atmospheric iron inputs (Fig. 1). The model tends to overestimate chlorophyll concentrations in the open-ocean areas of the Indian Ocean, and along the margins of the mid-ocean gyres during winter months. Thus, chlorophyll concentrations are too high in the South Pacific and South Atlantic during June (Fig. 4) and in portions of the North Pacific and North Atlantic during January (Fig. 5). It is likely that our assumption of a linear slope with depth for subsurface nutrients (see MET) is not valid in these regions and somewhat excessive nutrients are introduced as mixed layers deepen during winter months. In early spring, chlorophyll concentrations tend to be higher than observed with SeaWiFS in parts of 


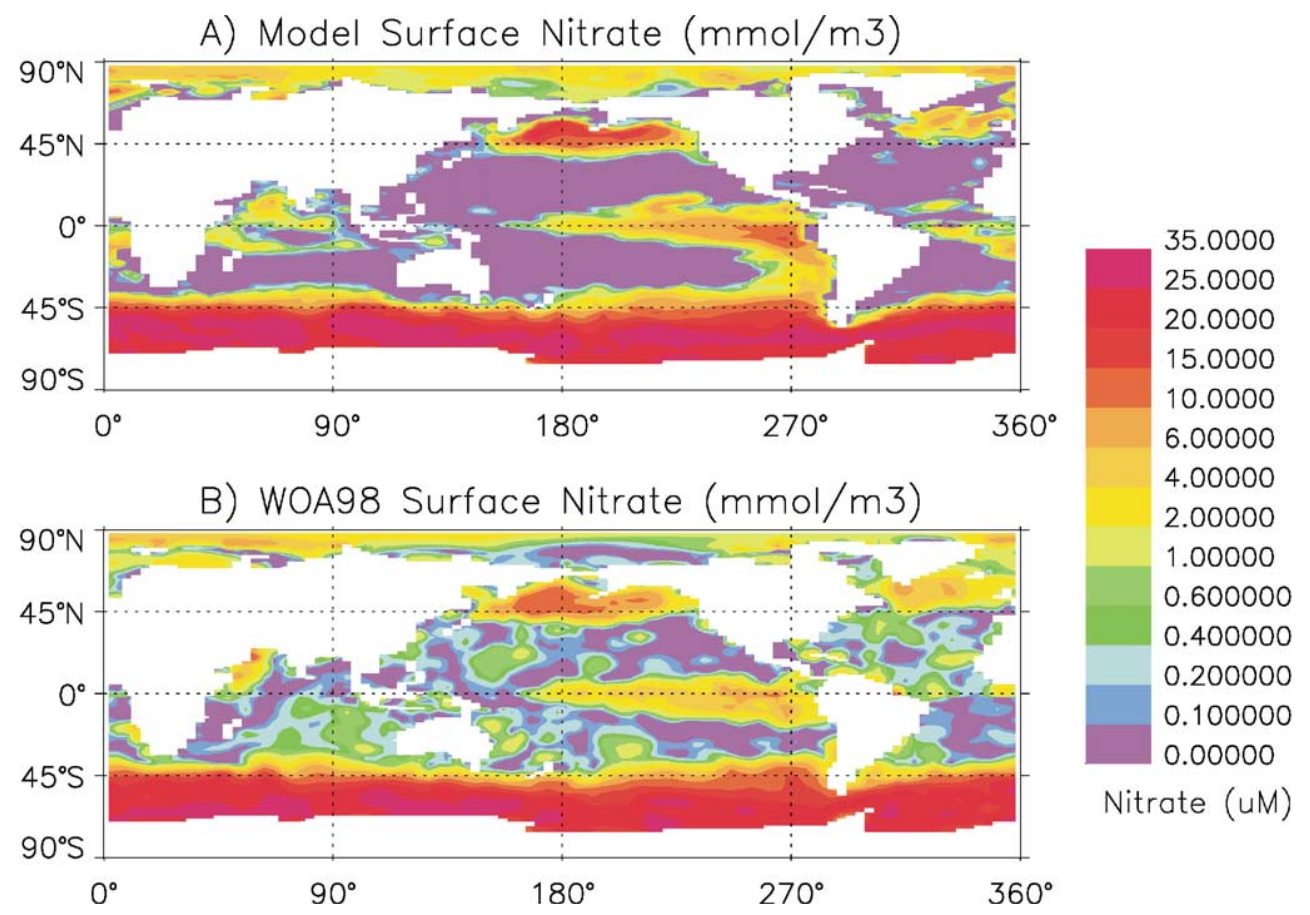

Fig. 3. Model estimates of surface mixed-layer nitrate concentrations during summer months (in each hemisphere) compared with the summer season nitrate data from the World Ocean Atlas 1998 (Conkright et al., 1998). (A) Model surface nitrate $\left(\mathrm{mmol} / \mathrm{m}^{3}\right)$. (B) WOA98 surface nitrate $\left(\mathrm{mmol} / \mathrm{m}^{3}\right)$.

the Southern Ocean as there is a modest bloom of the small phytoplankton as mixed layers shoal in some regions (not shown). Chlorophyll concentrations are almost uniformly low in this region by December driven by strong iron limitation.

Patterns of annual mixed-layer primary production from our standard model run are similar to water-column production estimates from the VGPM at the basin scale (Fig. 6). Since the VGPM estimates total euphotic zone production, absolute values should be higher than our model, which includes only the surface mixed layer. In general, there is very good agreement between the model and the satellite-based estimates for primary production. Highest production values are seen in the upwelling zones associated with the eastern boundary currents and in the Arabian Sea. Elevated production also is seen in the high-latitude North Atlantic and at mid-latitudes in the Southern Ocean in the Atlantic and Indian sectors, with low production in the Pacific (Fig. 6). The model production estimate is low in the eastern equatorial Pacific. This is due to persistently shallow mixed layers in the climatological forcings and due to the lack of advection in our model framework.

Export of biogenic carbon from the surface mixed layer within the large (sinking) detrital pool is compared with total biogenic carbon export (export due to sinking, detrainment, and turbulent mixing) from the surface mixed layer in Fig. 7. Sinking Particulate Organic Carbon (POC) accounts for $2 / 3$ of total global export out of the surface mixed layer. The spatial pattern of the sinking export is similar to total production with the highest export in areas where diatom blooms 


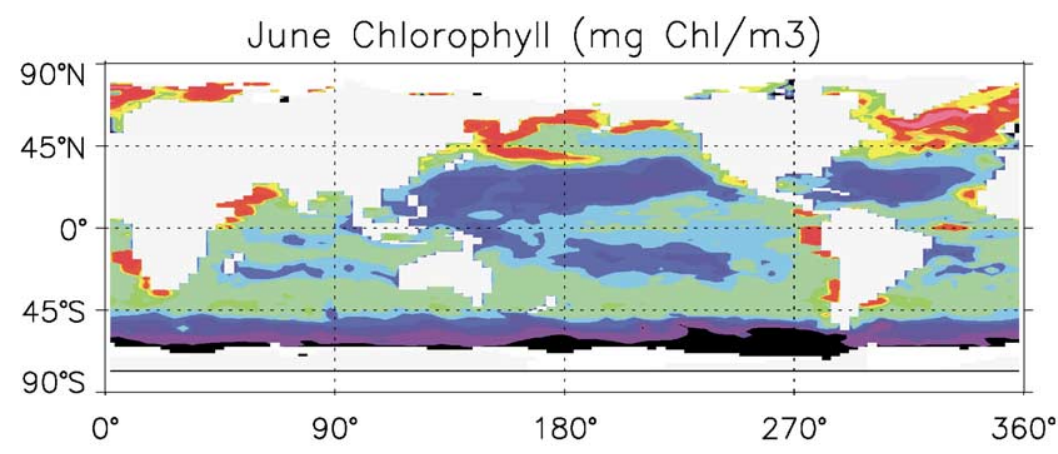

A) Global Mixed Layer Model,
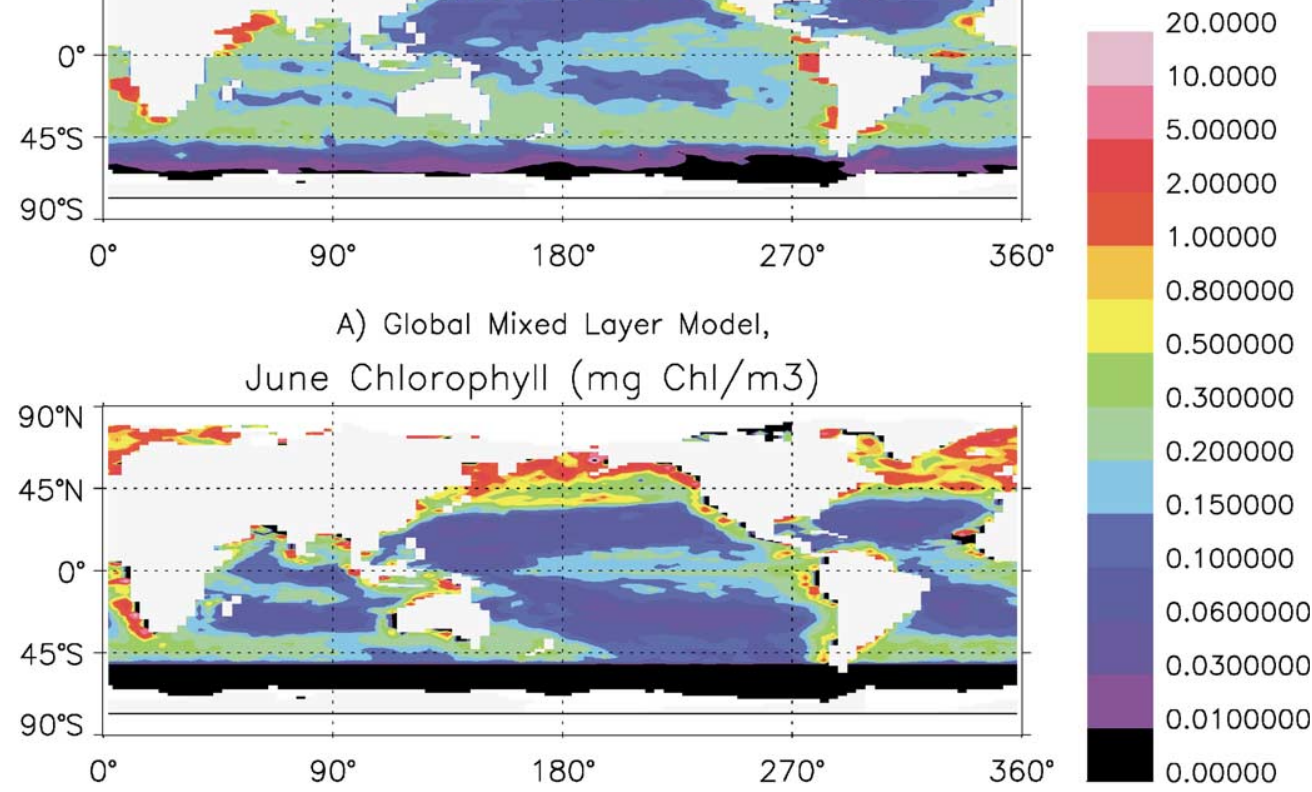

B) SeaWiFS Monthly Composite

$\mathrm{mg} \mathrm{Chl} / \mathrm{m} 3$

Fig. 4. Surface chlorophyll concentrations $\left(\mathrm{mg} \mathrm{chl} / \mathrm{m}^{3}\right)$ for the month of June from the ecosystem model (top panel) compared with satellite-derived estimates for June 1999 from SeaWiFS (bottom panel). (A) Global mixed-layer model. (B) SeaWiFS monthly composite.

occur (Figs. 6 and 7a). In the mid-ocean gyres, the small phytoplankton typically account for $>90 \%$ of production, and the sinking export is low, often accounting for less than half of the total carbon export (Fig. 7). A similar pattern is observed over much of the Southern Ocean, particularly in the southeast Pacific sector.

The maps of export production in Fig. 7 can be compared with export estimates from Laws et al. (2000). Laws et al. (2000) used VGPM output for total net production and estimated the export production as a function of temperature and net productivity, where the export function was determined using an ecological model validated with in-situ data from several locations. The overall export pattern of Laws et al. (2000) is similar to those in Fig. 7. Highest export was in coastal areas and the North Atlantic, with minimal export in mid-ocean gyres. In the Southern Ocean there was elevated export at mid-latitudes in the South Atlantic and south of Africa but less so in the Pacific sector, similar to the pattern seen in Fig. 7. Our model predicts higher export in the Southeast Indian sector of the Southern Ocean than that of Laws et al. (2000).

Next we examine nutrient-limitation patterns, which are a function of ambient nutrient concentrations relative to the half-saturation uptake constants for each phytoplankton class. Our focus is on summer months, which we define as June-August for the Northern Hemisphere and 


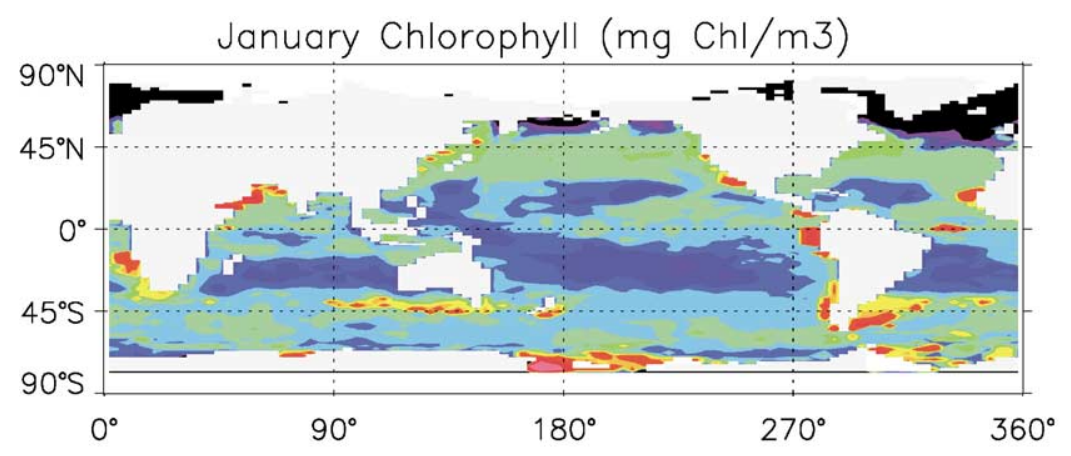

A) Global Mixed Layer Model,
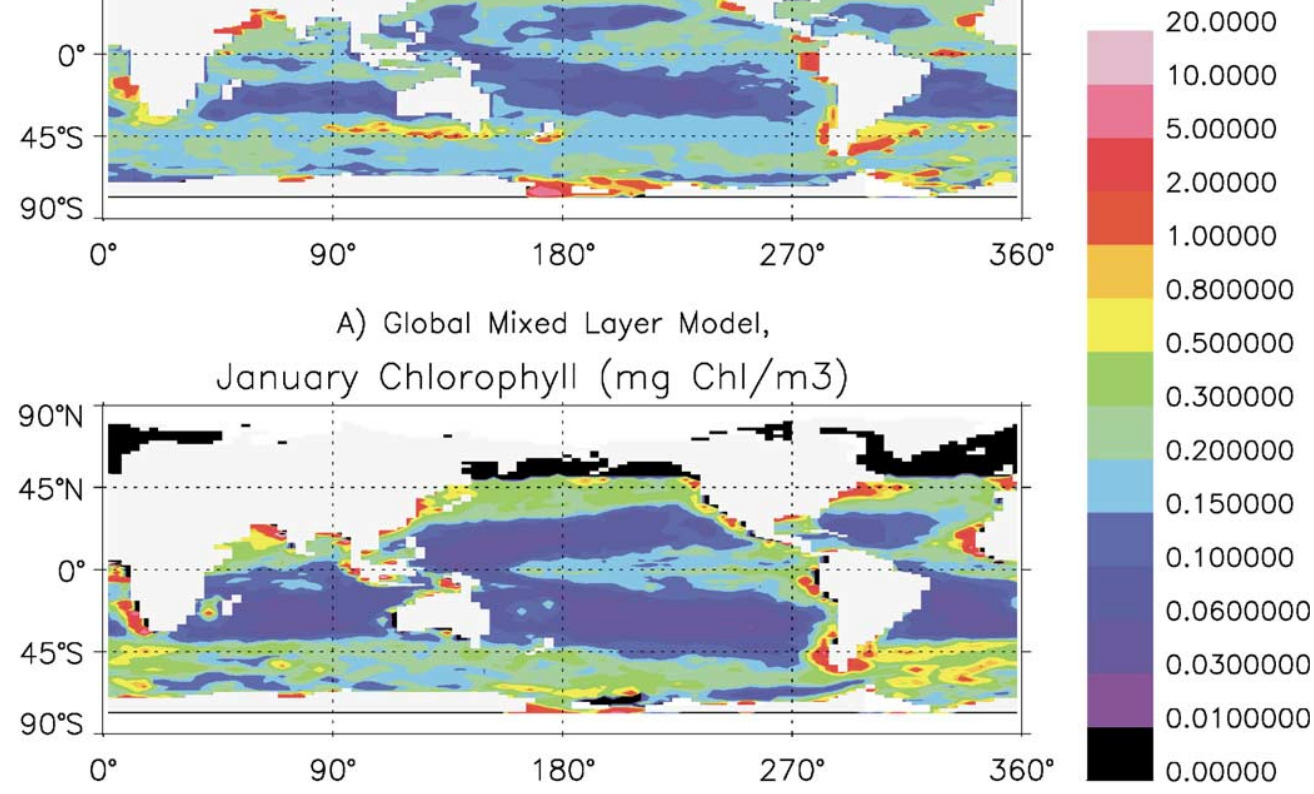

B) SeaWiFS Monthly Composite

$\mathrm{mg} \mathrm{Chl} / \mathrm{m} 3$

Fig. 5. Surface chlorophyll concentrations $\left(\mathrm{mg} \mathrm{chl} / \mathrm{m}^{3}\right)$ for the month of January from the ecosystem model (top panel) compared with satellite-derived estimates for January 1999 from SeaWiFS (bottom panel). (A) Global mixed-layer model. (B) SeaWiFS monthly composite.

December-February for the Southern Hemisphere. In the model the nutrient with the lowest cell quota relative to maximum quotas, limits carbon fixation (or growth rate) (MET). We define phytoplankton as nutrient-replete if all cell quotas are $>97 \%$ of their maximum values. Note that this is an arbitrary definition of nutrient replete status on our part. Increased radiation and shallow mixed-layer depths, generally precludes strong light limitation of phytoplankton growth (for the diatoms and small phytoplankton, not for the diazotrophs) during summer months, allowing us to focus on nutrient-limitation patterns. In the ecosystem model it is difficult to assess nutrient limitation during times of strong light limitation because nutrient cell quotas are calculated relative to cellular carbon (Geider et al., 1998; MET). Thus, when carbon fixation is negligible, phytoplankton are able to achieve maximum cell quotas even if uptake rates are very slow due to low ambient nutrient concentrations (see Figs. 11 and 12 in MET).

Maps showing summer season nutrient-limitation patterns for the three phytoplankton classes and the percentage of total ocean area where each nutrient is limiting are shown in Fig. 8. The mid-ocean gyres are N-limited for the diatoms and small phytoplankton while the HNLC regions of the subarctic and equatorial Pacific, and the Southern Ocean are Fe-limited (Fig. 8). Equatorial waters in the Indian and Atlantic oceans and portions of the North Atlantic also become 


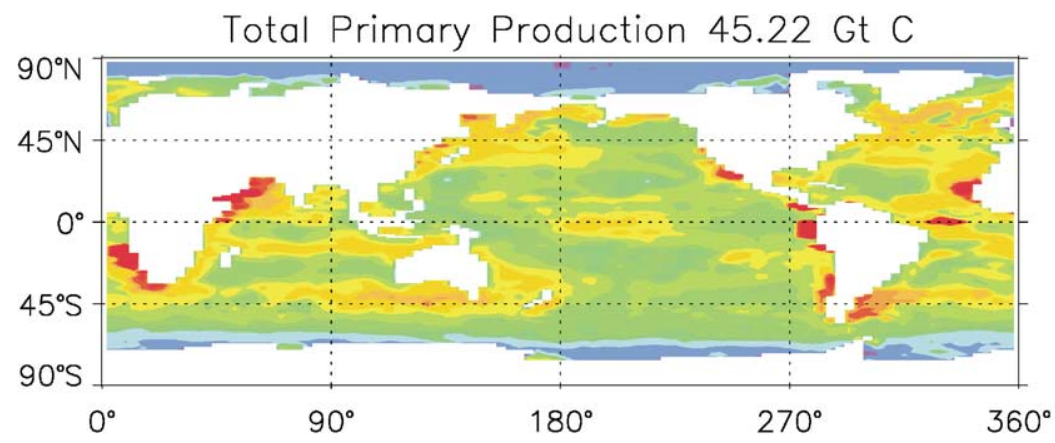

A) Ecosystem Model Mixed Layer Primary Production Total Primary Production 52.89 Gt C
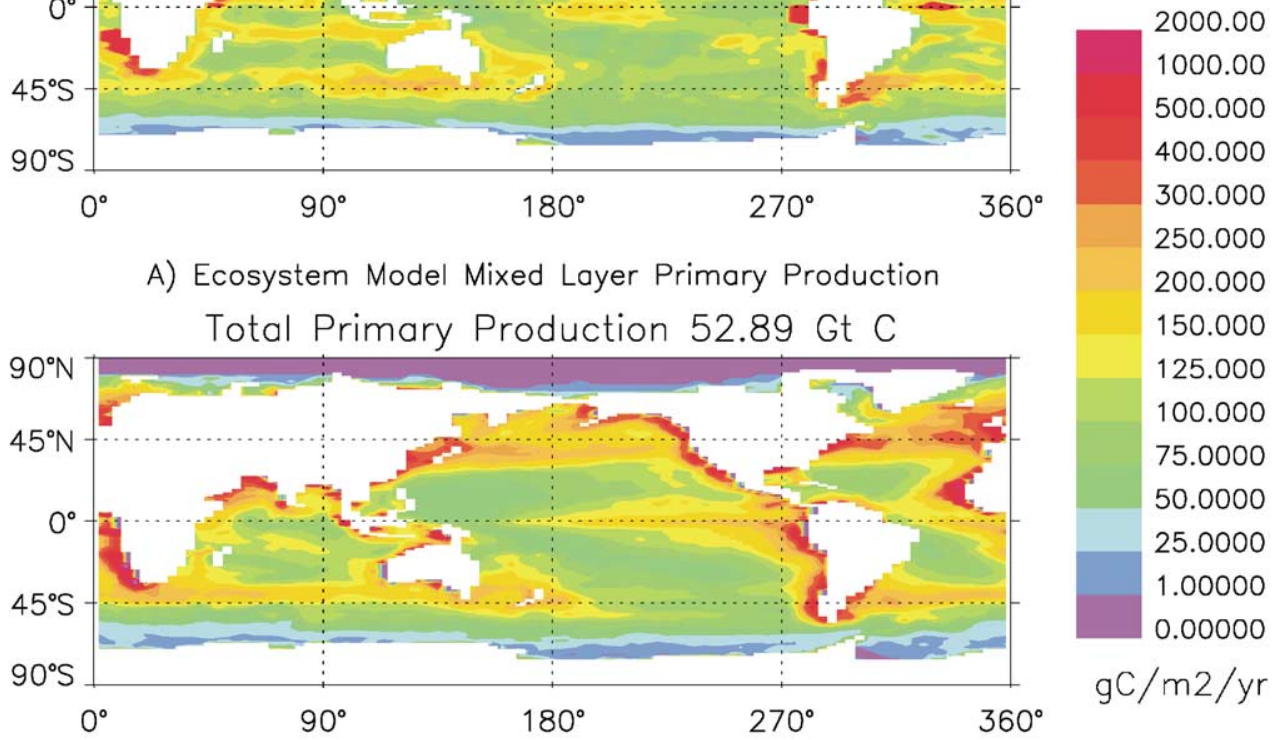

B) VGPM Water Column Primary Production

Fig. 6. Annual primary production (Gt C) within the surface mixed layer estimated by the ecosystem model (top panel) (A) compared with satellite-based estimates of total water column primary production from the Vertically Generalized Production Model (VGPM) (bottom panel)(B) of Behrenfeld and Falkowski (1997).

Fe-limited during summer months (Fig. 8). These patterns of Fe stress are similar to those estimated by Fung et al. (2000). Their analysis also showed modest Fe stress in the equatorial Atlantic and Indian Oceans, regions not usually associated with iron limitation (Fung et al., 2000).

Diatom growth rates are Si-limited in northern Subantarctic waters, in portions of the North Atlantic, equatorial Atlantic, and equatorial Pacific, and over much of the Arabian Sea (Fig. 8). The diatoms and small phytoplankton are nutrient replete only in areas permanently covered with heavy sea ice (where strong light limitation occurs) (Fig. 8). Nutrient-replete areas constitute $<1 \%$ of the ocean area for the diatoms and the small phytoplankton. In contrast, the diazotrophs are nutrient-replete over most of the world ocean.

Temperature is the dominant control on diazotroph growth at mid to high latitudes as we assume diazotroph production and biomass to be negligible when sea-surface temperature is $<16^{\circ} \mathrm{C}$. At the mid to low latitudes mixed-layer depth strongly influences both light and seasurface temperatures, and the diazotrophs thrive only in areas where mixed layers remain shallow of an extended period (see MET). The diazotrophs are nutrient-limited over $\sim 39 \%$ of the world ocean, with $\sim 35 \%$ Fe-limited and $\sim 4 \%$ P-limited (Fig. 8). Cold sea-surface temperatures prevent diazotroph growth at high latitudes over $\sim 29 \%$ of the world ocean. If this temperature 

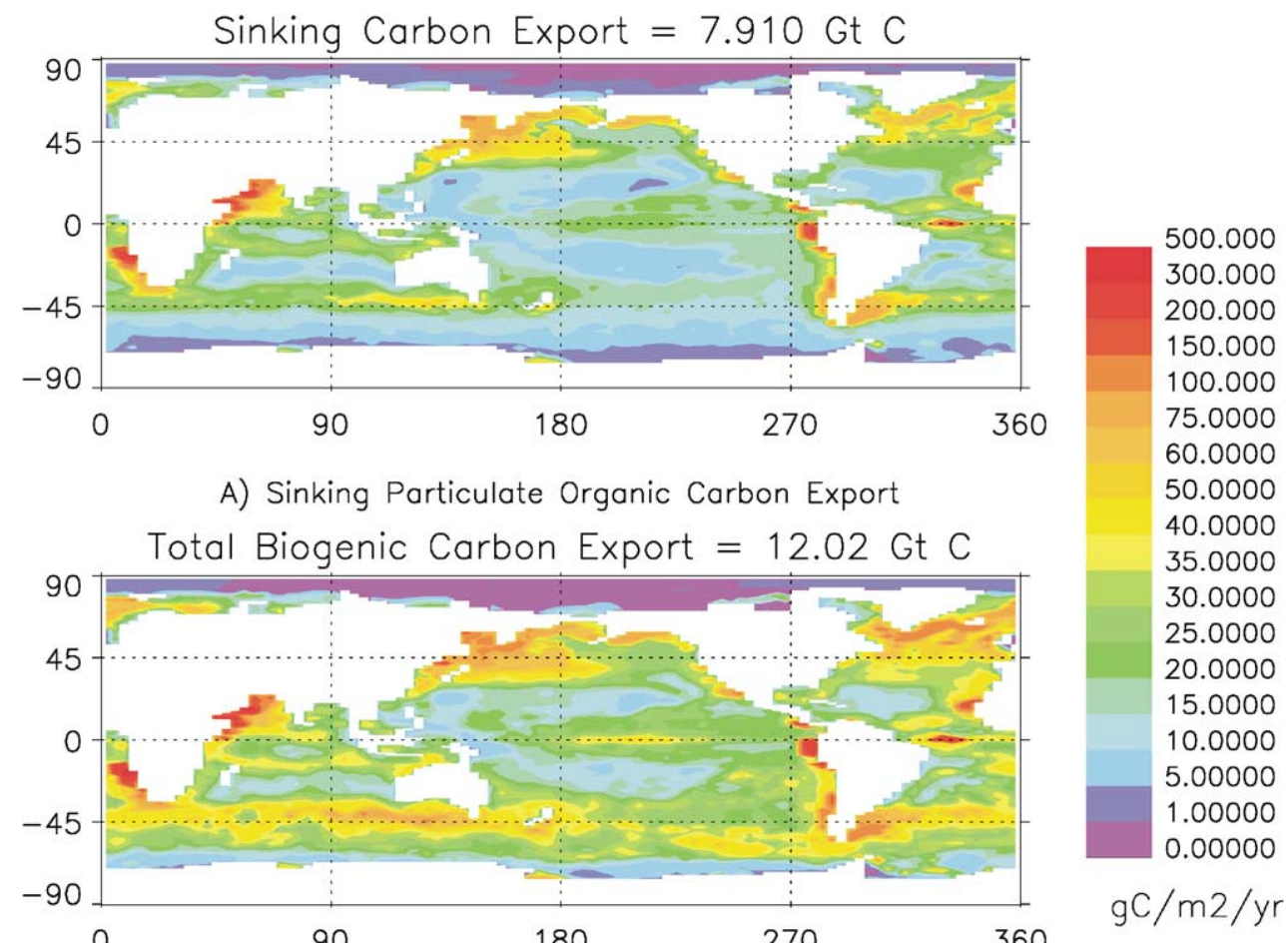

A) Sinking Particulate Organic Carbon Export

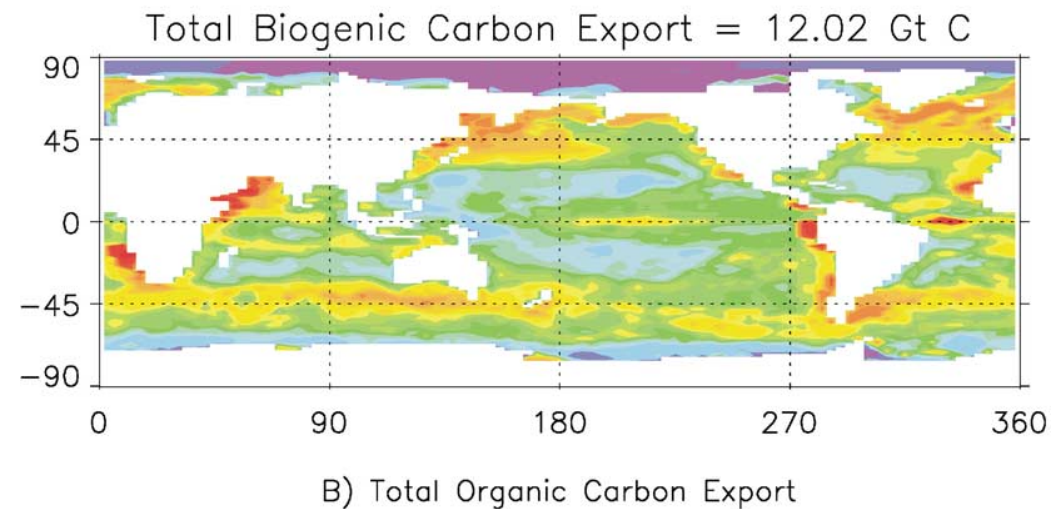

$\mathrm{gC} / \mathrm{m} 2 / \mathrm{yr}$

Fig. 7. The ecosystem model estimated annual export of biogenic carbon from the surface mixed layer (A, within the sinking detrital pool) and total biogenic carbon export (B). Total export is the sum of the sinking flux plus the export of biogenic carbon due to turbulent mixing at the base of the mixed layer and detrainment.

controlled area is excluded then $50 \%$ of the remaining tropical/subtropical area is Fe-limited, $5 \%$ is P-limited, and $45 \%$ is nutrient-replete (light- and/or temperature-limited). There are substantial areas of P limitation in the North Atlantic and western North Pacific (Fig. 8).

In general, only a small portion of the world ocean is P-limited for the three phytoplankton groups (Fig. 8). Significant portions of the North Atlantic are P-limited for the diazotrophs including at the BATS site (Fig. 8, MET). The diatoms also experience some P stress at BATS during summer months (although $\mathrm{N}$ is more strongly limiting, see MET). These results are consistent with the recent measurements showing much lower ambient dissolved inorganic phosphate levels in the North Atlantic near BATS relative to the North Pacific near the HOT site (Wu et al., 2000). McCarthy and Carpenter (1979) suggested that Trichodesmium may be P-limited in the central North Atlantic. Orcutt et al. (submitted) suggest that Trichodesmium colonies are not P-limited at BATS due to enhanced remineralization by bacteria associated with the colonies. However, mean Trichodesmium molar N/P ratios measured by Orcutt et al. (submitted) were considerably higher (57 for puffs and 125 for tufts) than the mean value of 45 reported for the HOT site in the North Pacific (Letelier and Karl, 1996), suggesting P stress is a possibility.

Both diatoms and smaller phytoplankton become Fe-limited in parts of the North Atlantic during summer months (Fig. 8). Unlike in the HNLC areas, the spring bloom depletes 


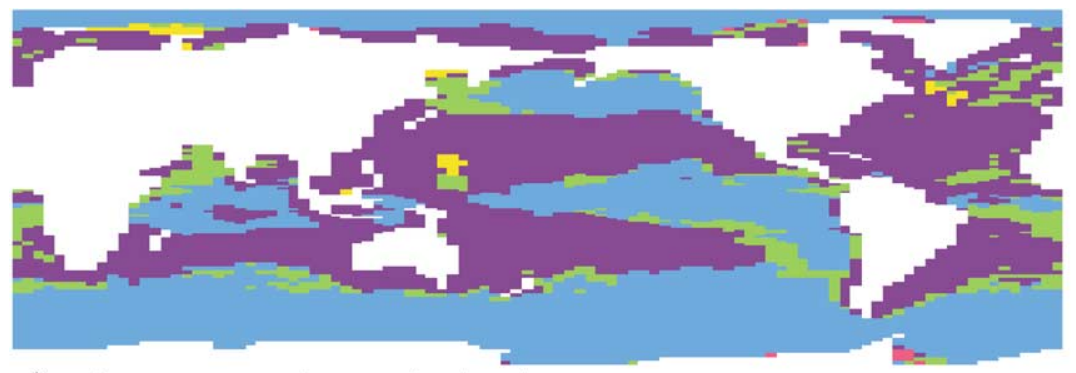

A) Diatom Nutrient Limitation

Nitrogen $50.04 \%$, Iron $38.75 \%$, Silica $10.57 \%$, Phosphorus $0.548 \%$, Replete $0.082 \%$

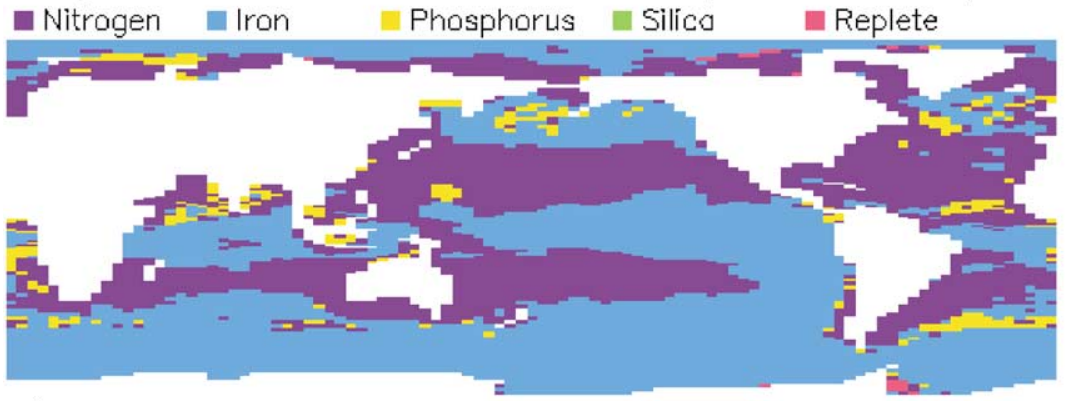

B) Small Phytoplankton Nutrient Limitation

Nitrogen $45.29 \%$, Iron $50.20 \%$, Phosphorus $4.405 \%$, Replete $0.089 \%$

nitrogen Iron Inosphorus Beplete

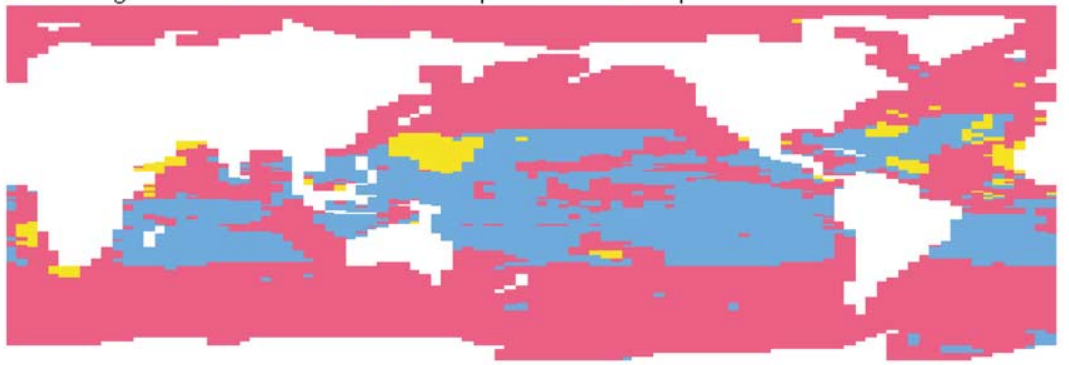

C) Diazotroph Nutrient Limitation

Nitrogen $0.000 \%$, Iron $35.33 \%$, Phosphorus $3.539 \%$, Replete $61.12 \%$

Fig. 8. Nutrient-limitation patterns for the diatoms (A), the small phytoplankton (B), and the diazotrophs (C) during summer months. Areas where all nutrient cell quotas are $>97 \%$ of the maximum cell quota values are arbitrarily defined as nutrient-replete. Also shown is the percentage of total ocean area where each nutrient is limiting growth.

macronutrients and the initially high iron concentrations in this region (see January concentrations in Fig. 2, and MET). Most field evidence suggests that Fe limitation does not play a strong role in this region (Martin et al., 1993; Sunda, 1997), and high chlorophyll concentrations are seen throughout the summer in the SeaWiFS data. There are several possible explanations for Fe limitation in the model. Advection from nearby continental sources may play a role in delivering iron to this region (Martin et al., 1993; Fung et al., 2000). The atmospheric source may be underestimated. The dust flux to the North Atlantic is much higher in MAH99 


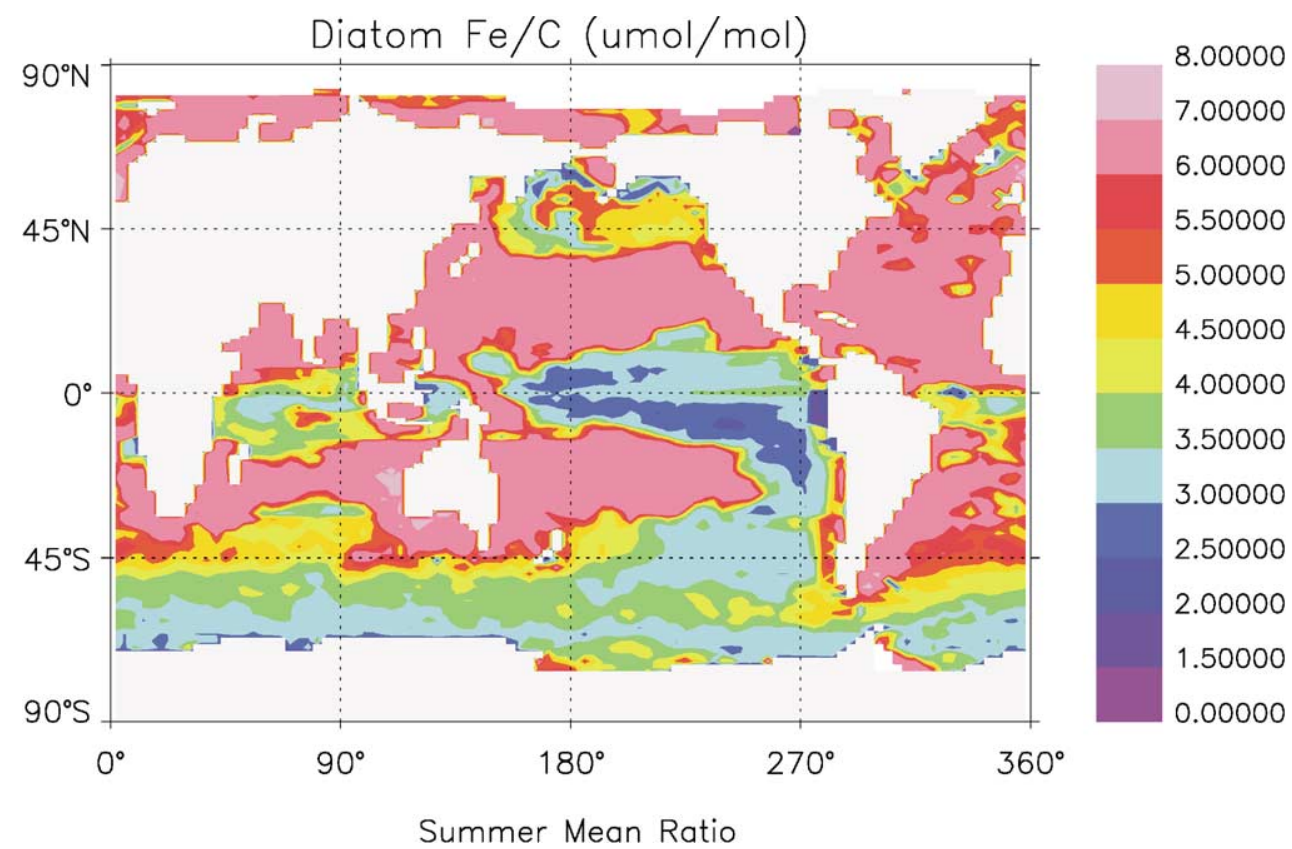

Fig. 9. Mean cellular $\mathrm{Fe} / \mathrm{C}(\mu \mathrm{mol} / \mathrm{mol})$ ratios for the diatoms during summer months.

than in TF95 (Fig. 1). The increased flux in MAH99 was during the month of January, when the dust plume from northern Africa was advected northward within the atmosphere. A similar event occurring once during summer months would likely prevent Fe limitation in this region. Alternatively, the solubility of the iron within atmospheric dust may be higher in this region due to anthropogenic influence from North America and Europe (see Jickells and Spokes, in press). Iron limitation is also a real possibility, particularly towards the end of the summer season as dust inputs are generally low. The results of Fung et al. (2000) suggested strong iron limitation in this region.

The cellular Fe $/ \mathrm{C}$ ratio ( $\mu \mathrm{mol} / \mathrm{mol}$ ) of the diatoms during summer months is shown in Fig. 9. In areas where iron is not strongly limiting, $\mathrm{Fe} / \mathrm{C}$ ratios approach the maximum cell quota value of $7.0 \mu \mathrm{mol} / \mathrm{mol}$ (see MET). The lowest ratios ranging from $2-3.5 \mu \mathrm{mol} / \mathrm{mol}$ are seen in the most Felimited regions of the equatorial Pacific and Southern Ocean and in some coastal regions where phytoplankton blooms have depleted iron (Fig. 9). Intermediate values $(3.5-5 \mu \mathrm{mol} / \mathrm{mol})$ are seen in less Fe-stressed areas of the equatorial Pacific and the subarctic Northeast Pacific. In the equatorial Pacific there are generally higher $\mathrm{Fe} / \mathrm{C}$ ratios north of the equator than south of the equator (Fig. 9). This is a result of the higher atmospheric iron inputs north of the equator (Fig. 1a). Note also that within the strong upwelling region on the equator in the Pacific sector there are somewhat higher $\mathrm{Fe} / \mathrm{C}$ ratios than in surrounding waters, reflecting the higher iron inputs from below (Fig. 9). The Fe/C ratios for the small phytoplankton in the model display a very similar spatial pattern, but the low ratios in the Fe-limited regions are higher than the diatoms by $1-2 \mu \mathrm{mol} / \mathrm{mol}$. The small phytoplankton are not as iron stressed in these regions due to their lower half-saturation constants for iron uptake (MET). The dynamic $\mathrm{Fe} / \mathrm{C}$ ratios in the 
model output, which result from varying degrees of Fe-stress, are similar to the regional values assigned by Fung et al. (2000). Tortell et al. (1996) measured $\mathrm{Fe} / \mathrm{C}$ ratios of eukaryotic phytoplankton at Station P in the northeast subarctic Pacific of 4.4. The model results for this region are in excellent agreement (Fig. 9). The model results are also in good agreement with Sunda (1997), who estimated $\mathrm{Fe} / \mathrm{C}$ ratios in sinking matter at several hundred meters depth of $\sim 2 \mu \mathrm{mol} / \mathrm{mol}$ for the equatorial Pacific and Southern Ocean, $\sim 3.5 \mu \mathrm{mol} / \mathrm{mol}$ for the subarctic North Pacific, and $>7 \mu \mathrm{mol} / \mathrm{mol}$ for the North Atlantic.

Model phytoplankton $\mathrm{C} / \mathrm{N}$ ratios are near the Redfield value of $6.6(\mathrm{~mol} / \mathrm{mol})$ for all phytoplankton classes during summer months, except in the mid-ocean gyres and high latitude North Atlantic, areas that are strongly $\mathrm{N}$-limited. In these areas $\mathrm{C} / \mathrm{N}$ ratios for the small phytoplankton are typically $8.5-10.0(\mathrm{~mol} / \mathrm{mol})$ with molar ratios of $10-12$ in the most N-limited areas. The diatoms are more $\mathrm{N}$-stressed due to their higher half-saturation constants (MET) and $\mathrm{C} / \mathrm{N}$ ratios can reach values 3 times the Redfield value. In the most strongly Fe-limited regions, $\mathrm{C} /$ $\mathrm{N}$ ratios fall below the Redfield ratio. Similarly, N/P ratios for the diatoms and small phytoplankton are close to the Redfield value except in the $\mathrm{N}$-limited areas where $\mathrm{N} / \mathrm{P}$ ratios are considerably lower. Diazotroph molar N/P ratios are close to their optimum value of 45.0 everywhere except in the P-limited regions, where much higher ratios are observed. Small phytoplankton $\mathrm{C} / \mathrm{Chl}$ ratios $(\mathrm{g} / \mathrm{mg}$ ) range from 30 to 125 during summer months. Similar values are seen for the diatoms, except in the most $\mathrm{N}$-limited regions, where values in excess of $200 \mathrm{~g} /$ $\mathrm{mg}$ ) are observed. Nitrogen uptake is a requirement for chlorophyll synthesis in the model (MET). In the mid-ocean gyres the diatoms are strongly N-limited (Fig. 7 and MET) and are not able to obtain sufficient nitrogen for chlorophyll synthesis. The diazotrophs have lower $\mathrm{C} / \mathrm{Chl}$ ratios typically $<50(\mathrm{~g} / \mathrm{mg})$ due to their lower initial slope of the P vs. I curve (MET).

The relative strength of the atmospheric iron source is compared with total inputs of dissolved iron to the surface mixed layer in Fig. 10. Total dissolved iron input is calculated as the sum of atmospheric dissolved iron inputs plus the entrainment, upwelling, and turbulent mixing of dissolved iron into the surface mixed layer. In areas of deep winter mixing, such as the North Atlantic and the southeast Pacific sector of the Southern Ocean, large amounts of iron are entrained during winter months and then detrained unused by the biota in the spring, as mixed layers shoal. In these areas the atmospheric source is quite small by comparison $(<5 \%$, Fig. 10). In areas of high dust flux (near NW Africa, Australia, the Arabian Peninsula) the atmospheric source for iron dominates inputs to the surface mixed layer (compare Figs. 1a and 10). In these regions surface-layer iron concentrations are higher than below the mixed layer. The atmospheric source also dominates inputs in strongly stratified regions with moderate to high dust deposition (the central North Pacific, the western South Pacific Gyre, and the Sargasso Sea). In areas with low dust input the atmospheric contribution is typically $<30 \%$ (compare Figs. 1a and 10). In general, areas where the atmospheric iron source accounts for $<50 \%$ of total inputs tend to become Fe-limited during summer months (Figs. 8 and 10). In these regions, variations in the atmospheric Fe source will lead directly to variations in total and export production. In the Southern Ocean there is a latitudinal gradient with considerable regional variability (Fig. 10). The southeast Pacific sector of the Southern Ocean, where deposition accounts for $<5 \%$ of total iron inputs, is an area of very low dust deposition (Fig. 1) and relatively deep winter mixed layers. De Baar et al. (1999) argued for strong iron limitation in this region far from continental and shelf sources of iron. The atmospheric input is higher in the southwest Atlantic sector of the Southern 


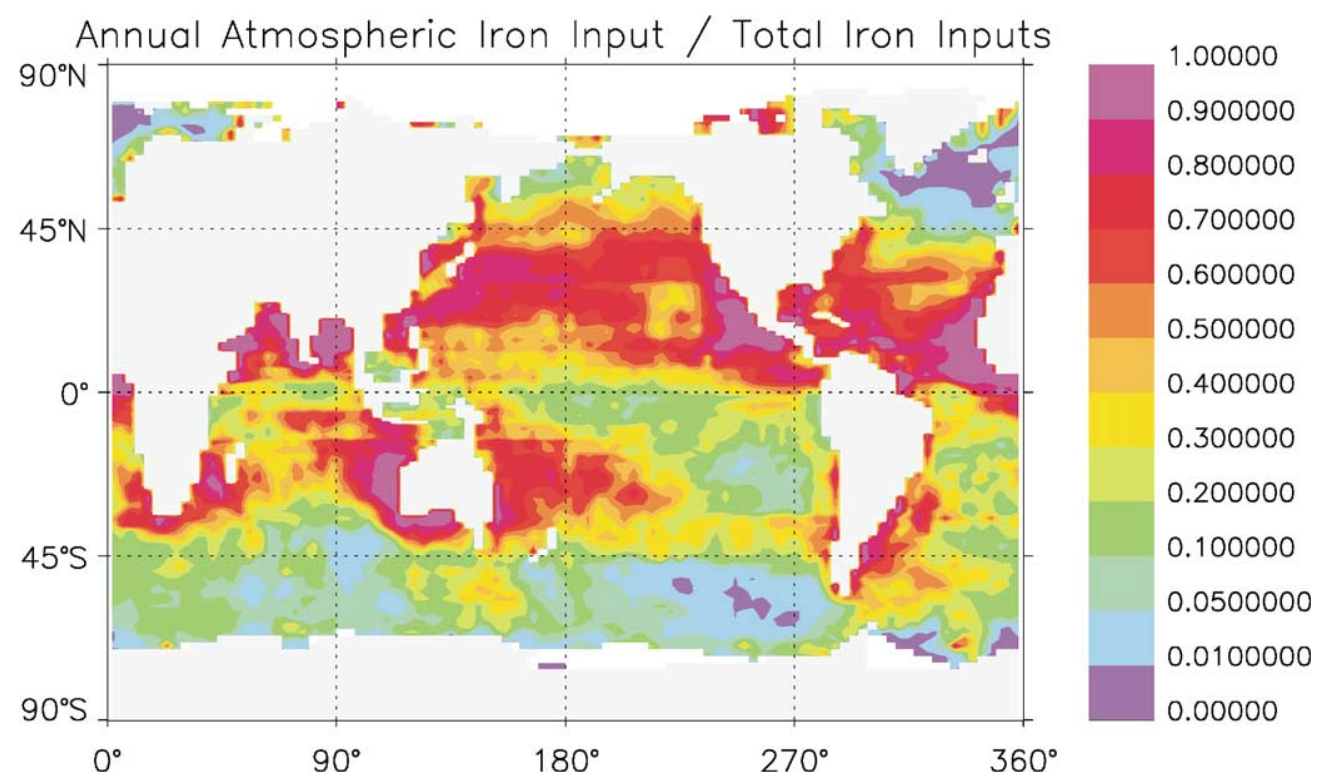

Fig. 10. The relative size of the atmospheric dissolved iron source relative to total dissolved iron inputs to the surface mixed layer. Total dissolved iron input is calculated as the sum of the atmospheric source plus dissolved iron inputs due to entrainment, upwelling and turbulent mixing.

Ocean (30-50\%) (Fig. 10). This is an area with generally elevated chlorophyll concentrations in the SeaWiFS data set (Moore and Abbott, 2000).

We can compare these estimates of the atmospheric contribution with literature values. Fung et al. (2000) estimated that the atmospheric contribution would be $\sim 17-29 \%$ of total inputs in the equatorial Pacific and Southern Ocean and exceed 60\% in most other regions (assuming 2\% solubility). Our results are in general agreement (Fig. 10). Gordon et al. (1997) estimated the atmospheric source at $3-29 \%$ of iron inputs in the equatorial upwelling zone at $140^{\circ} \mathrm{W}$. Our model results range from $5 \%$ to $30 \%$ for this region (Fig. 10). Duce (1986) estimated that atmospheric deposition should dominate iron inputs in the Central North Pacific Gyre and in the Sargasso Sea. The analysis of Bruland et al. (1994) suggests that surface waters north of Hawaii $\left(\sim 28^{\circ} \mathrm{N}\right)$ should be strongly dominated by the aeolian input due to strong stratification and shallow mixed layers, in good agreement with the model results (Fig. 10). This also suggests a dominant atmospheric source in other oligotrophic regions with moderate to high dust inputs like the Sargasso Sea, in agreement with our results (Fig. 10). Löscher et al. (1997) estimated that atmospheric deposition accounts for $\sim 9 \%$ of iron inputs at $56^{\circ} \mathrm{S} \times 15^{\circ} \mathrm{W}$ in the Atlantic sector of the Southern Ocean. Our estimates for this region are in the range of 10-30\%. Löscher et al. (1997) used the deposition estimate of Duce and Tindale (1991) for the atmospheric source but noted that Kumar et al. (1995) had suggested much higher deposition rates (by a factor of 10) for this region based on an analysis of ocean sediment core data.

Martin and Gordon (1988) calculated that atmospheric iron deposition was $84-93 \%$ of total inputs at Station $\mathrm{P}\left(50^{\circ} \mathrm{N}, 145^{\circ} \mathrm{W}\right)$. Löscher et al. (1997) also argued that the atmospheric source should dominate in this region ( $\sim 85 \%$ of iron inputs). Our model results suggest the atmospheric 
source is $<50 \%$ (Fig. 10). We suggest that the importance of the atmospheric source has been previously overestimated for this region. Both Martin et al. (1989) and Löscher et al. (1997) used an assumed solubility of $10 \%$, which as discussed previously is likely too high. At a solubility of $2 \%$ the atmospheric source of Löscher et al. (1997) would be reduced to $50 \%$ of total inputs. Martin et al. (1989) used the high end of the iron flux estimated by Duce (1986) for the central North Pacific. Dust fluxes in the central North Pacific are significantly higher than at Station P (Fig. 1). The iron concentrations measured by Martin et al. (1989) generally increase steadily with depth in this region, suggesting substantial inputs from below. There is no strong subsurface minimum as Bruland et al. (1994) found in the central North Pacific Gyre. If we increase the solubility to $10 \%$ in our model, this region is no longer Fe-limited and large diatom blooms occur.

The relative contribution of atmospheric iron inputs displayed in Fig. 10 are based on annual iron budgets, and as noted include large amounts of iron entrained during deep winter mixing and then detrained (unused by the biota) as mixed layers shallow in the spring. If this analysis is restricted to summer months (a time of maximum stratification and typically the strongest $\mathrm{Fe}$ limitation), the atmospheric source accounts for a significantly higher percentage of total iron inputs. During summer months the atmospheric iron input is more than $90 \%$ of total iron input throughout the subarctic North Pacific, and is $>20 \%$ of total dissolved iron inputs over much of the North Atlantic and most of the Southern Ocean (compare these values with Fig. 10). In the southeast Pacific sector of the Southern Ocean the atmospheric contribution is still $<5 \%$ during summer months.

Annual surface mixed-layer nitrogen fixation predicted by the ecosystem model is displayed in Fig. 11. The total is $62.4 \mathrm{Tg} \mathrm{N}$ for the world ocean, comparable to the global estimate of $80 \mathrm{Tg} \mathrm{N}$ by Capone et al. (1997). However, significant amounts of nitrogen fixation occur below the surface mixed layer (Letelier and Karl, 1996, 1998). So total fixation might be in better agreement with the geochemical based estimates, which exceed $100 \mathrm{Tg}$ N (i.e. Gruber and Sarmiento, 1997). The spatial patterns of elevated nitrogen fixation (Fig. 11) are in good agreement with the limited field data available. The model is in very good agreement with field measurements of nitrogen fixation at HOT and BATS (Karl et al., 1997; Orcutt et al., 2001; see MET). High Trichodesmium biomass has been documented in the Caribbean Sea and in the waters off the northern coast of South America (see Lipschultz and Owens, 1996). Relatively high rates also have been reported for the central North Pacific gyre (Letelier and Karl, 1996, 1998; Karl et al., 1995, 1997). Satellite observations have revealed large trichodesmium blooms along the northern coast of Australia (Capone et al., 1997). High rates of $\mathrm{N}$ fixation also have been observed in the Arabian Sea, the NE Caribbean Sea, and the SE East China Sea (Capone et al., 1997, and references therein; Capone et al., 1998). Lastly, satellite observations and in situ work have shown repeated Trichodesmium blooms in the southwest, tropical Pacific from $\sim 15-25^{\circ} \mathrm{S}$ and $165-180^{\circ} \mathrm{E}$ (Dupouy et al., 2000). The model predictions are in excellent agreement, showing high nitrogen fixation in this region (Fig. 11).

The dominant controls on nitrogen fixation in the model are temperature at the high latitudes and Fe, temperature and light at mid to low latitudes (both SST and light levels are influenced by mixed-layer depth). Nutrient limitation of the diazotrophs was seen over $\sim 39 \%$ of the world ocean during summer months (Fig. 8). However, in subtropical and tropical regions, nitrogen fixation rates are largely a function of mixed-layer depth, with enhanced nitrogen fixation seen in areas with persistently shallow mixed-layer depths where sufficient diazotroph biomass builds up 

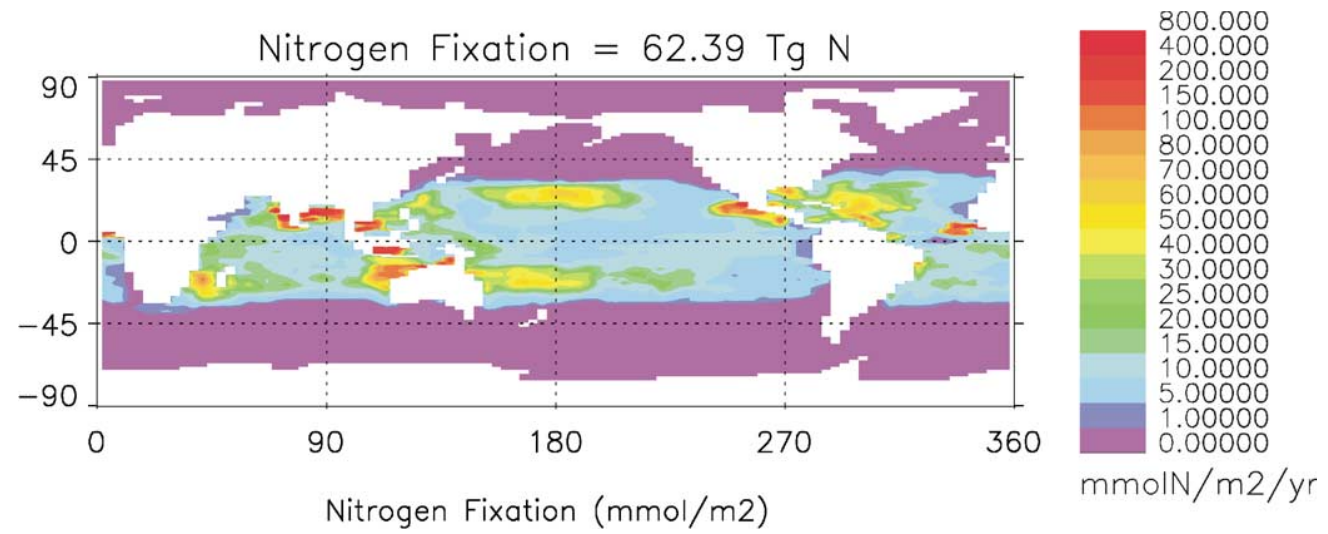

Fig. 11. Model predicted surface mixed layer annual nitrogen fixation $(\operatorname{Tg} \mathrm{N})$ by the diazotrophs.

(MET). This is consistent with the increased $\mathrm{N}$ fixation in the North Pacific during periods of increased stratification associated with ENSO events (Karl et al., 1995). It is also in agreement with the hypothesis of Hansell and Feely (2000) that stratification (as influenced by precipitation patterns) is the dominant control on $\mathrm{N}$ fixation in the western tropical Pacific. Hansell and Feely (2000) suggested that climate change, which leads to increased stratification, should increase nitrogen fixation. Our model results strongly support this hypothesis, and it may be that global scale nitrogen fixation will increase if surface waters warm and stratification increases as expected over the next century.

Fe limitation is also playing a key role in regulating nitrogen fixation at the global scale in our model. In an alternate model run where the ecosystem model was forced with the dust deposition estimates for the LGM by Mahowald et al. (1999) at an assumed solubility for iron of $10 \%$, global nitrogen fixation increased to $149 \mathrm{Tg} \mathrm{N}$. There were also large increases in total primary and export production (Table 4). This atmospheric iron flux is probably the upper bound of what can be considered in the realm of possibility, and resulted in the diazotrophs being iron-replete over all but a small fraction of the world ocean $(\sim 2 \%$ Fe limited, see Table 5$)$. Thus, with near total relief from iron stress, global $\mathrm{N}$ fixation more than doubled compared with our standard run (Fig. 11). Interestingly, the increases in this LGM dust flux run came mainly in the areas of relatively high $\mathrm{N}$ fixation ( $>25 \mathrm{mmol} \mathrm{N} / \mathrm{m}^{2} / \mathrm{yr}$ ) seen in Fig. 11. There was essentially no increase in $\mathrm{N}$ fixation in the areas from Fig. 11 with $<15 \mathrm{mmol} \mathrm{N} / \mathrm{m}^{2} / \mathrm{yr}$. In these areas, light is strongly limiting diazotroph growth. In the other regions, where near optimum light and temperature conditions occur for a substantial period (the regions with $>25 \mathrm{mmol} \mathrm{N} / \mathrm{m}^{2} / \mathrm{yr}$ in Fig. 11), as diazotroph biomass increases iron is rapidly depleted (due to the relatively high diazotroph cell quota for $\mathrm{Fe}$ ) leading to Fe-limitation of growth rates. Comparing Figs. 8 and 11 it can be seen that many of the Fe limited regions for the diazotrophs are areas where there is moderate to high annual nitrogen fixation. It is the moderate to high diazotroph biomass that has depleted much of the available iron. The diatoms and small phytoplankton are typically nitrogen limited in these areas. An exception is in the eastern South Pacific where there is iron limitation and low nitrogen fixation. This is a region of very low atmospheric dust deposition (Fig. 1).

Globally the diazotrophs account for $<1 \%$ of total primary production. Diazotrophs account for $5-10 \%$ of primary production during summer months in the regions where annual $\mathrm{N}$ fixation 

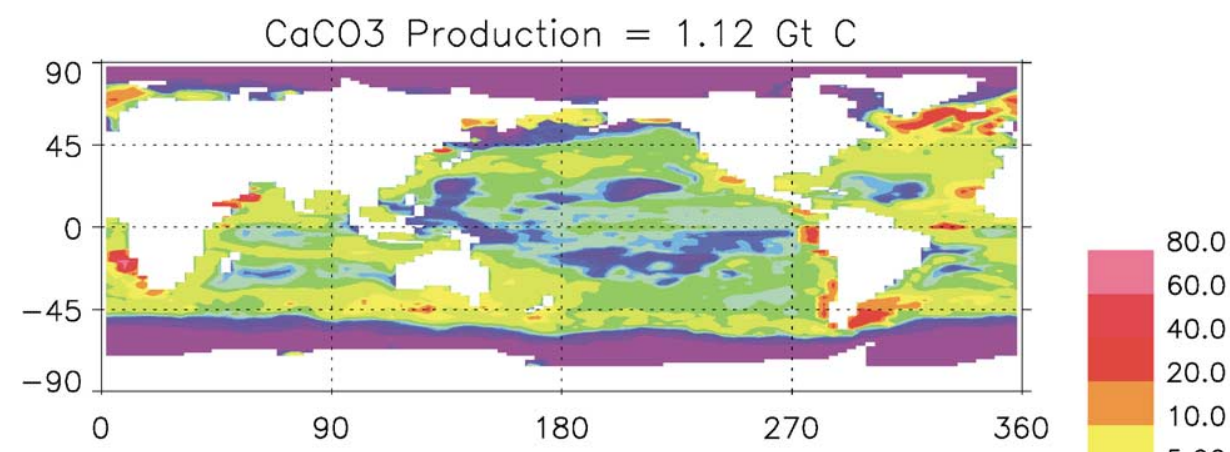

A) Phytoplankton $\mathrm{CaCO} 3$ Production
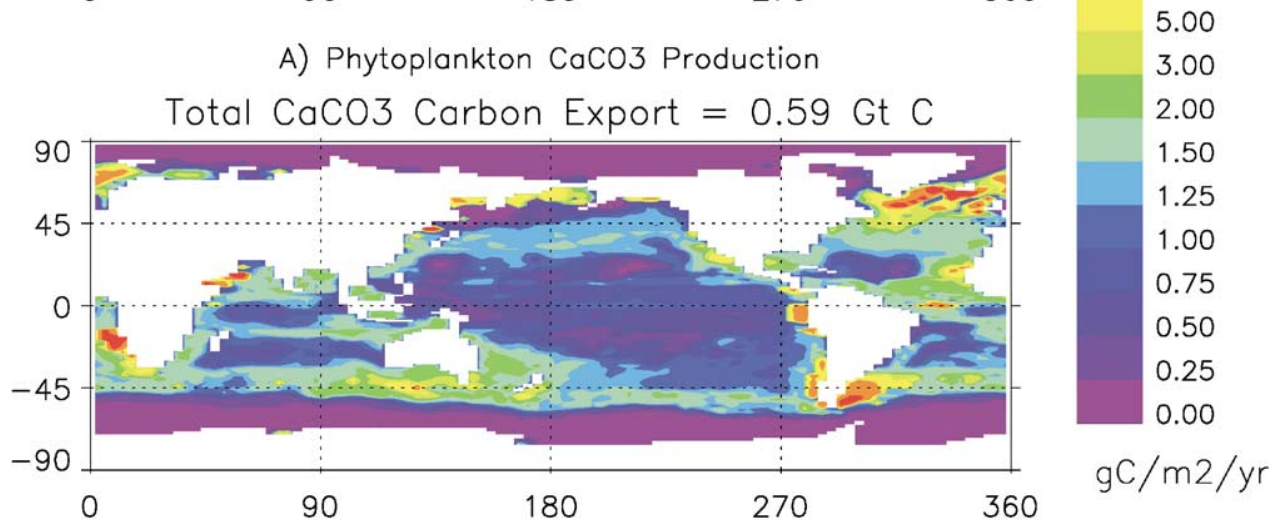

B) Sinking Flux of $\mathrm{CaCO} 3$

Fig. 12. Annual calcium carbonate production (Gt C) by phytoplankton (A) and the sinking calcium carbonate export (B) predicted by the model.

exceeds $\sim 40 \mathrm{mmol} \mathrm{N} / \mathrm{m}^{2} / \mathrm{yr}$ (see Fig. 11). Diazotroph production exceeds $30 \%$ of total primary production during summer months in some portions of the northern Indian Ocean where $\mathrm{N}$ fixation rates are quite high (see Fig. 11). Recall that diazotroph production is fueled exclusively by "new" nitrogen in the model (MET). The diazotrophs also have a stimulatory effect on the other phytoplankton through release of DON (see MET, and following sections). For the areas in Fig. 11 where nitrogen fixation is $<\sim 40 \mathrm{mmol} \mathrm{N} / \mathrm{m}^{2} / \mathrm{yr}$, the dominant loss term for the diazotrophs is the non-grazing mortality term (see MET), accounting for $>90 \%$ of all losses. Grazing becomes an important loss term only in areas of high diazotroph biomass and can account for more than $50 \%$ of total mortality in the areas where the diazotrophs bloom (Fig. 11).

The model predicted production and export of calcium carbonate by phytoplankton is shown in Fig. 12. The spatial patterns seen in Fig. 12 are generally in very good agreement with the synthesis of Milliman (1993) of a large number of sediment trap studies of calcium carbonate export. Milliman (1993) noted that the highest calcium carbonate fluxes out of surface waters were in the upwelling regions associated with eastern boundary currents and the upwelling zone in the Arabian Sea. Lowest fluxes were from the mid-ocean gyres and the highest latitudes (coldest waters) in each hemisphere (Milliman, 1993). The model predictions in Fig. 12 are in excellent agreement with these regional patterns. The high latitude North Atlantic is known to be a site of 
frequent coccolithophore blooms and high calcium carbonate export (Holligan et al., 1993; Robertson et al., 1994). In general, the spatial patterns of high calcium carbonate export are also in good agreement with satellite estimates of coccolithophore bloom distributions (Brown and Yoder, 1994; Iglesias-Rodríguez et al., submitted). The model predicts less calcium carbonate export in the equatorial Pacific, but does reproduce the high values suggested by Milliman (1993) for the equatorial Atlantic. Model $\mathrm{CaCO}_{3}$ production in the equatorial Pacific was less than that measured by Balch and Kilpatrick (1996) along $140^{\circ} \mathrm{W}$ (see MET).

Global production estimated by our parameterization of calcification is $1.12 \mathrm{Gt} \mathrm{C}$ of $\mathrm{CaCO}_{3} / \mathrm{yr}$ with a sinking export of $0.59 \mathrm{Gt} \mathrm{C}$. Milliman et al. (1999) estimate surface calcium carbonate production of $0.70 \mathrm{Gt} \mathrm{C}$, lower than our total. Given our sinking export for POC of $7.91 \mathrm{Gt} \mathrm{C}$, the globally integrated "rain ratio", the ratio of inorganic/organic carbon, at the base of the mixed layer is 0.075. This is in good agreement with the estimate of Yamanaka and Tajika (1996) of a global rain ratio out of surface waters in the $0.08-0.1$ range. This ratio would increase with depth as organic carbon is remineralized more rapidly than $\mathrm{CaCO}_{3}$. There was considerable spatial variability in the rain ratio with values of $<0.05$ in the central ocean gyres and over much of the equatorial Pacific and values of $0.1-0.2$ in the regions of high calcium carbonate export. The rain ratio exceeded 0.4 in portions of the high-latitude North Atlantic. Approximately 53\% of the calcium carbonate produced in surface waters is exported out of the surface mixed layer (Fig. 12). This is in general agreement with the estimate of Milliman et al. (1999) that $60-80 \%$ of the calcium carbonate produced in surface waters dissolves at depths $<1000 \mathrm{~m}$. Martin et al. (1993) reported a $50 \%$ decrease in the sinking calcium carbonate flux between 150 and $1000 \mathrm{~m}$ depth from floating sediment traps in the North Atlantic (see discussion in Milliman et al., 1999). If our surface export value of $0.59 \mathrm{Gt} \mathrm{C}$ declined by a similar amount, the resulting flux at $1000 \mathrm{~m}$ of $0.3 \mathrm{Gt} \mathrm{C}$ would be in excellent agreement with the estimate of Milliman et al. (1999) for calcium carbonate export to the deep sea at $1000 \mathrm{~m}$. Yamanaka and Tajika (1996) estimated the export of calcium carbonate out of surface waters to be $0.8-1.0 \mathrm{Gt} \mathrm{C}$.

\subsection{Global iron and carbon budgets for the surface mixed layer}

Next we examine global annual iron fluxes for the surface mixed layer (Table 2). Recall that we make assumptions about biota and detrital concentrations below the mixed the layer (see Methods section). This leads to a small entrainment of biogenic iron when the mixed layer deepens (within the biota and detrital pools) equal to $1.8 \%$ of total iron inputs (Table 2). The atmospheric iron source accounts for $27 \%$ of total iron inputs to the surface mixed layer. This is somewhat misleading as large amounts of iron are entrained during deep winter mixing at high latitudes (particularly in the North Atlantic) and then detrained from the mixed layer in the spring unused by the biota (Table 2). This detrainment of is of equal magnitude to the total dissolved iron entrained from below (Table 2). Detrainment of dissolved iron occurs in the mainly in highlatitude areas and also in areas of high dust flux (Fig. 1). In the regions of high dust flux, dissolved iron in the mixed layer exceeds concentrations below the mixed layer and turbulent mixing at the base of the mixed layer exports dissolved iron (3.5\% of total iron export, Table 2). Turbulent mixing of dissolved iron into the mixed layer over the rest of the ocean roughly balances this loss but in spatially distinct areas (Table 2). Fung et al. (2000) estimated the flux into the surface layer from subsurface sources at $0.7 \times 10^{9} \mathrm{~mol} \mathrm{Fe} / \mathrm{yr}$ for the open ocean. This is much lower than our 
Table 2

The annual iron budget for the surface mixed layer of the world ocean from the standard model run ${ }^{\mathrm{a}}$

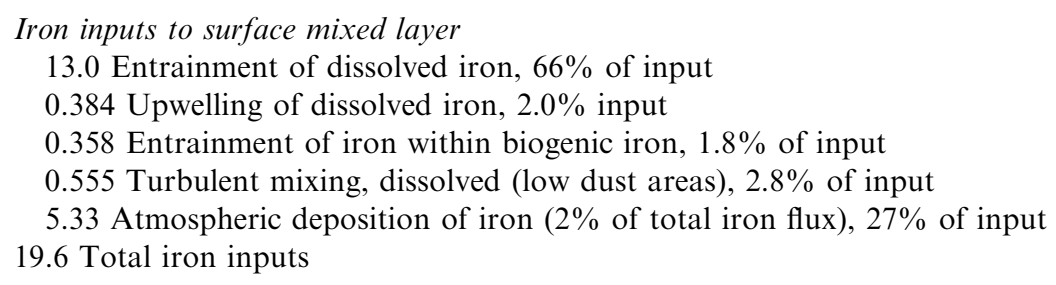

Iron export from surface mixed layer

13.0 Detrainment of dissolved iron, $65 \%$ of export

1.45 Detrainment of biogenic iron, $7.3 \%$ of export

0.708 Turbulent mixing, dissolved iron (high dust areas), 3.5\% of export

0.424 Turbulent mixing base of mixed layer, biogenic iron, $2.1 \%$ of export

4.21 Sinking of large detrital pool out of mixed layer, $21 \%$ of export

0.205 Dilution/Export of biogenic iron due to upwelling, $1.0 \%$ of export

20.0 Total iron exports

Iron cycling within surface mixed layer

15.7 Small phytoplankton uptake, $73 \%$ of total uptake

4.76 Diatom uptake, $22 \%$ of total uptake

1.01 Diazotroph uptake $4.7 \%$ of total uptake

21.5 Total uptake by phytoplankton

1.27 Scavenging of dissolved iron, equivalent to $5.9 \%$ of total biota uptake

10.1 Remineralization of small detritus iron, $60 \%$ of total remineralization

0.761 Remineralization of large detritus iron, $4.5 \%$ of total remineralization

5.92 Remineralization due to grazing, $35 \%$ of total remineralization

16.8 Total remineralization within surface mixed layer

\footnotetext{
${ }^{a}$ Atmospheric iron deposition was from the study of Tegen and Fung (1995) with an assumed 2\% solubility. Fluxes given in units of $10^{9} \mathrm{~mol} \mathrm{Fe} / \mathrm{yr}$. Biogenic iron includes the iron within the phytoplankton, zooplankton, and detrital pools. A portion of the iron within the large detrital pool is due to abiotic scavenging of iron (see text for details).
}

estimate but does not include entrainment during deep winter mixing, which accounts for much of the difference. We also set a higher subsurface iron concentration in coastal waters (see MET).

Sinking of the large detrital pool accounts for $21 \%$ of iron export (Table 2). This would include some scavenged iron (mainly in the high dust regions), which is added to the large detrital pool. Detrainment of dissolved iron dominates total export. The sinking flux accounts for $60 \%$ of total export if the detrainment of dissolved iron is excluded. Detrainment of biogenic iron is also a significant loss term (7.3\% of total export, Table 2). Most of the biogenic iron exported by detrainment and turbulent mixing is within the detrital pools that dominate standing stocks (see MET). We do not track the biogenic matter exported laterally in upwelling regions (it is not added to adjacent grid points), thus there is a small net loss of biogenic iron from the surface mixed layer due to upwelling (Table 2 ). This loss is only $1 \%$ of total "export" globally but locally can be a significant loss term. The small phytoplankton account for $73 \%$ of the iron uptake by phytoplankton (Table 2). Fung et al. (2000) estimated a similar total iron uptake by phytoplankton ranging from $12 \times 10^{9} \mathrm{~mol} \mathrm{Fe} / \mathrm{yr}$ for the open ocean to $26 \times 10^{9} \mathrm{~mol} \mathrm{Fe} / \mathrm{yr}$ for 
the global ocean. Scavenging of dissolved iron is equivalent to $6 \%$ of phytoplankton uptake and is concentrated in areas of high dust flux and some coastal areas where dissolved iron exceeds $0.6 \mathrm{nM}$ and scavenging rates are higher (MET).

The annual carbon budget for the surface mixed layer is given in Table 3 . The small phytoplankton account for $75 \%$ of primary production, the diatoms $24 \%$, and the diazotrophs $0.49 \%$. Note that while accounting for $<1 \%$ of primary production, the diazotrophs account for nearly $5 \%$ of iron uptake by phytoplankton due to their higher cell quotas for iron (Tables 2 and 3). Sinking POC (within the large detrital pool) exports $17.5 \%(7.9 \mathrm{Gt} \mathrm{C})$ of primary production or $17.0 \%$ of the total biogenic carbon inputs (Table 3). Laws et al. (2000) estimated the sinking particulate flux accounts for $\sim 20 \%$ of total production within the euphotic zone at the global scale. The sinking flux accounts for $66 \%$ of total carbon export, with detrainment accounting for $23 \%$ and turbulent mixing $7.3 \%$ (Table 3). Thus, mixing and detrainment are significant routes for export of biogenic carbon from the surface mixed layer. Most of the carbon detrained from the mixed layer is within the small detrital pool. Total export of carbon from the mixed layer accounts for $26 \%(12.0 \mathrm{Gt} \mathrm{C})$ of carbon losses, with the remaining $74 \%$ remineralized within the mixed layer.

There are strong regional patterns in the modes of carbon export. In some low-productivity areas the detrainment flux accounts for $>50 \%$ of total carbon export from the mixed layer. In the mid-ocean gyres the sinking flux often accounts for $<50 \%$ of carbon export, with detrainment of $30-40 \%$ and turbulent mixing accounting for 10-20\% (see Fig. 7). Carlson et al. (1994) estimated that detrainment of dissolved organic carbon in the northwestern Sargasso Sea during winter mixing could exceed the particulate sinking carbon flux. The turbulent mixing loss is significant even though we assume some biota and detritus beneath the mixed layer. In the equatorial Pacific, coastal waters, and over much of the northern Indian Ocean, export is dominated by the sinking flux ( $>80 \%$ of total export). In the subarctic North Pacific and the North Atlantic the sinking flux accounts for $\sim 50-70 \%$ of total export. In the Southern Ocean sinking is the main mode of export in coastal waters, but accounts for $<50 \%$ in most open ocean areas, especially in the Pacific Sector where detrainment accounts for $>50 \%$ of total export (Fig. 7).

Grazing is the dominant loss term for the diatoms and small phytoplankton classes (Table 3 ). Annually grazing consumes $\sim 80-90 \%$ of primary production at low to mid-latitudes $\left(<45^{\circ}\right)$. In the upwelling zones where phytoplankton blooms occur, grazing consumes $\sim 30-60 \%$ of production. At high latitudes grazing accounts for $40-70 \%$ of primary production; in some regions, notably Antarctic coastal waters, it is $<30 \%$. In areas where phytoplankton blooms occur, aggregation/sinking losses account for $20-40 \%$ of total phytoplankton losses, much higher than the global mean aggregation/sinking loss of $6 \%$ for the small phytoplankton and $12 \%$ for the diatoms (Table 3). In general, grazing is the dominant loss term in regions where the small phytoplankton dominate the assemblage (see MET). This is consistent with a large body of field work examining the role of microzooplankton grazing on small phytoplankton (Strom and Welschmeyer, 1991; Landry et al., 1995, 1997; Lessard and Murrell, 1998). For the diazotrophs, the dominant loss term is the non-grazing mortality term $(74 \%$ of total), with grazing losses accounting for most of the remainder (Table 3).

Comparing total carbon fixation (Table 3) with total iron uptake by phytoplankton (Table 2) gives a mean phytoplankton cellular $\mathrm{Fe} / \mathrm{C}$ ratio $(\mu \mathrm{mol} / \mathrm{mol})$ of 5.7 , similar to the mean value of 5.0 suggested by Johnson et al. (1997). The Johnson et al. (1997) data may be weighted toward areas 
Table 3

Carbon budget for the surface mixed layer of the world ocean from the standard model run ${ }^{\mathrm{a}}$

Carbon sources to mixed layer ecosystem model

28.4

9.09

0.185

37.7

0.984

38.7

Carbon losses from mixed layer ecosystem model

$$
6.59
$$

0.733

0.377

10.0

16.8

0.692

10.6

28.1

38.1

Phytoplankton losses

(\% total loss)

\section{Grazing}

Aggregation

Non-grazing mortality

Other Losses

(mixing/detrain)

Total loss
Small phytoplankton primary production, $75 \%$ of total production

Large phytoplankton primary production, $24 \%$ of total production

Diazotroph primary production, $0.49 \%$ of total production

Total primary production, $(=45.3 \mathrm{Gt} \mathrm{C})$

Entrainment of biogenic carbon, equivalent to $2.6 \%$ of primary production

Total carbon inputs to ecosystem model, $(=46.4 \mathrm{Gt} \mathrm{C})$,

Sinking particulate export within large detrital pool, $66 \%$ of export

Turbulent mixing of biogenic carbon out of mixed layer, $7.3 \%$ of export

Detrainment of biogenic carbon out of mixed layer, 23\% of export

Dilution/Export due to upwelling, 3.8\% of export

Total export, $(=12.0 \mathrm{Gt} \mathrm{C}), 26 \%$ of total carbon loss

Remineralization of small detritus, $60 \%$ of remineralization

Remineralization of large detritus, $2.5 \%$ of remineralization

Remineralization due to grazing, $38 \%$ of remineralization Total remineralization within mixed layer, $=33.8 \mathrm{Gt} \mathrm{C}$, or $74 \%$ of total carbon loss

Total sinks (export + remineralization)

Small phytoplankton Diatoms Diazotrophs

Zooplankton biomass budget

9.07

8.83

0.24

28.4

New zooplankton biomass ( $=30 \%$ of total grazing)

Zooplankton Mortality, $97 \%$ of total loss
$5.89(65 \%)$

$1.12(12 \%)$

$1.92(21 \%)$

$0.16(1.8 \%)$

9.09

0.185
$0.040(22 \%)$

$0.0(0 \%)$

$0.137(74 \%)$

$0.008(4.3 \%)$

$0.41(1.4 \%)$

Detrainment, Turbulent Mixing, Upwell/Dilution, 2.7\% of total loss

${ }^{\mathrm{a}}$ Fluxes given in units of $10^{14} \mathrm{~mol} \mathrm{C} / \mathrm{yr}$. Biogenic carbon includes carbon within the phytoplankton, zooplankton, and detrital pools. 
with lower $\mathrm{Fe} / \mathrm{C}$ ratios because many of the samples come from Fe-stressed areas of the subarctic and equatorial Pacific and the Southern Ocean.

\subsection{Silicon cycling in surface waters}

Total biogenic silica production by the diatoms in our model is $2.3 \times 10^{14} \mathrm{~mol} \mathrm{Si} / \mathrm{yr}$. This is in excellent agreement with the global estimate of $2.4 \times 10^{14} \mathrm{~mol} \mathrm{Si} / \mathrm{yr}$ by Tréguer et al. (1995). Nelson et al. (1995) argued that at least $50 \%$ of the silica produced by diatoms dissolves in the upper $100 \mathrm{~m}$ of the water column. The sinking export of biogenic $\mathrm{Si}$ at the base of the mixed layer predicted by the model is $1.4 \times 10^{14} \mathrm{~mol} \mathrm{Si} / \mathrm{yr}$, which would be lower if normalized to $100 \mathrm{~m} \mathrm{depth}$, and thus is in good agreement with Nelson et al. (1995). Comparing diatom carbon production (Table 3) with the biogenic Si production of $2.3 \times 10^{14} \mathrm{~mol} \mathrm{Si} / \mathrm{yr}$ gives a mean molar $\mathrm{Si} / \mathrm{C}$ ratio for the diatoms of 0.25 . Nelson et al. (1995) estimated a mean ratio of 0.13 for low-latitude diatoms and 0.18 for Antarctic diatoms based on nutrient-replete culture studies (Brzezinski, 1985; Carbonell, 1985). These culture studies would not have accounted for the Fe effect on Si uptake and quotas. Nelson et al. (1995) also noted the this ratio can vary widely, from 0.03 to 0.42 in the two culture studies, with field measurements in the Antarctic as high as 0.81 (Tréguer et al., 1991).

Global atmospheric deposition of soluble $\mathrm{Si}$ is $1.76 \times 10^{11} \mathrm{~mol} \mathrm{Si} / \mathrm{yr}$ in our standard model run (based on the TF95 dust deposition and assuming a 7.5\% solubility, see MET). Duce et al. (1991) estimated a soluble $\mathrm{Si}$ deposition of $7.5 \times 10^{11} \mathrm{~mol} \mathrm{Si} / \mathrm{yr}$ (assuming $7.5 \%$ solubility). The difference is largely driven by the large particulate dust deposited nearshore, which is not included in TF95. Thus, our atmospheric Si inputs (and perhaps Fe inputs) are likely underestimated in coastal regions near the primary dust sources. Tréguer et al. (1995) assumed an eolian input of $5.0 \times 10^{11} \mathrm{~mol} \mathrm{Si} / \mathrm{yr}$ in their global budget based on Duce et al. (1991) and as assumed solubility of $5.0 \%$. Atmospheric Si deposition had only a limited impact on the marine ecosystem at the global scale. In an alternate model run with no atmospheric Si input, global primary production, sinking export production and spatial patterns of nutrient limitation were nearly identical to our standard model run (Tables 4 and 5). The atmospheric Si input can have a significant impact on ecosystem dynamics in some regions, particularly areas of high dust input like the Arabian sea (see MET).

The interaction between silica and iron dynamics in the model can lead to seasonal shifts in nutrient limitation. In the ecosystem model we include an iron effect on Si cell quota, such that maximum cell quota increases with increasing iron stress (see MET). Thus, under Fe stress the ratio of $\mathrm{Si}$ uptake/ $\mathrm{N}$ uptake and cellular $\mathrm{Si} / \mathrm{N}$ and $\mathrm{Si} / \mathrm{C}$ ratios are increased. There is field and laboratory evidence for these effects (Takeda, 1998; Hutchins and Bruland, 1998; Hutchins et al., 1998; De La Rocha et al., 2000; Brzezinski et al., 2001). To examine the influence of this iron effect on nutrient uptake by diatoms, we did an alternate run of the model without this effect (i.e. constant maximum Si cell quota). Global primary and export production were not significantly affected (Table 4). However, large areas that are Si-limited in Fig. 8 are shifted to either Fe or $\mathrm{N}$ limitation in the alternate run (Table 5). The Si-limited area declines by $50 \%$ with most areas shifted to Fe limitation. In the equatorial Pacific, most of the Si-limited areas in Fig. 8 are not Silimited in the alternate run; large decreases in the Si-limited areas are also seen in Subantarctic waters. This suggests the $\mathrm{Fe}$ effect on $\mathrm{Si} / \mathrm{N}$ drawdown is important in determining nutrientlimitation patterns in these regions. This is consistent with the findings of Leynaert et al. (2001) that half-saturation constants for Si uptake in the equatorial Pacific were close to ambient silicate 
Table 4

The influence of atmospheric iron inputs to the ocean on total mixed-layer primary production and the sinking export of particulate organic carbon (POC) in the large detrital pool ${ }^{\mathrm{a}}$

\begin{tabular}{|c|c|c|c|c|}
\hline Atmospheric input & $\begin{array}{l}\text { Primary production } \\
(\mathrm{Gt} \mathrm{C})\end{array}$ & $\begin{array}{l}\text { POC export } \\
\text { (Gt C) }\end{array}$ & $\%$ Export & $\begin{array}{l}\text { Nitrogen fixation } \\
(\operatorname{Tg} N)\end{array}$ \\
\hline No Atmospheric Input & 35.0 & 5.81 & 16.6 & 33.6 \\
\hline \multicolumn{5}{|l|}{ Tegen and Fung (1995) } \\
\hline $2 \% \mathrm{~b}$ & 45.2 & 7.92 & 17.5 & 62.4 \\
\hline $4 \%$ & 49.5 & 8.99 & 18.2 & 82.5 \\
\hline $6 \%$ & 52.1 & 9.69 & 18.6 & 97.4 \\
\hline $10 \%$ & 56.1 & 10.7 & 19.1 & 116.0 \\
\hline \multicolumn{5}{|l|}{ Mahowald et al. (1999) } \\
\hline $2 \%$ & 42.1 & 7.22 & 17.2 & 61.3 \\
\hline $4 \%$ & 44.1 & 7.65 & 17.3 & 73.3 \\
\hline $6 \%$ & 45.4 & 7.97 & 17.6 & 82.9 \\
\hline $10 \%$ & 47.0 & 8.44 & 18.0 & 96.8 \\
\hline LGM $2 \%$ & 56.1 & 11.2 & 19.9 & 122.0 \\
\hline LGM $10 \%$ & 66.1 & 14.3 & 21.7 & 149.0 \\
\hline Saturating Atmospheric Input & 70.5 & 16.5 & 23.4 & 142.0 \\
\hline \multicolumn{5}{|l|}{ Alternate model runs, TF $2 \%$} \\
\hline No Fe affect on Si quota & 45.1 & 8.02 & 17.8 & 61.8 \\
\hline$K_{\mathrm{s}}$ for $\mathrm{Si}=3.0 \mathrm{mmol} / \mathrm{m}^{3}$ & 45.3 & 7.84 & 17.3 & 64.0 \\
\hline No Atms. Si deposition & 45.0 & 7.89 & 17.5 & 62.6 \\
\hline No Diazotrophs & 43.7 & 7.66 & 17.5 & 0.0 \\
\hline $\mathrm{Fe}$ quotas increased by $25 \%$ & 42.3 & 7.32 & 17.3 & 56.0 \\
\hline
\end{tabular}

${ }^{a}$ Atmospheric iron deposition to the oceans is based on dust deposition from the model studies of Tegen and Fung (1995) and Mahowald et al. (1999) with varying percentages of iron solubility. Both modern day and last glacial maximum (LGM) inputs are used from Mahowald et al. (1999). Total surface mixed-layer nitrogen fixation by the diazotrophs is also displayed. Also shown are results from several alternate model runs all forced with the Tegen and Fung (1995) atmospheric iron deposition at 2\% solubility (see text for details).

${ }^{\mathrm{b}}$ Standard model run.

concentrations. Thus, a $\sim 1 \mu \mathrm{M}$ decrease in ambient silicate concentrations due to iron stress (as was observed in the model output at the EQPAC site, see MET) could significantly affect nutrientlimitation patterns. Boyd et al. (1999) suggested silica or Fe and Si co-limitation of diatom growth was likely during summer months in Subantarctic waters SE of New Zealand, and that light and/ or Fe were the likely limiting during the spring. In the standard run (Fig. 8), Si limitation has resulted in many areas (4.3\% of world ocean) due to stronger drawdown of ambient silicate concentrations because of Fe stress. De La Rocha et al. (2000) suggested this pattern was possible, where strong Si drawdown as a function of iron stress leads to Si limitation, based on diatom culture work (see also Nelson et al., 2001).

Dugdale and Wilkerson (1998) argued that diatom production in the equatorial Pacific upwelling zone should be limited by Si. They used a half-saturation constant for Si uptake of $3 \mathrm{mmol} \mathrm{Si} / \mathrm{m}^{3}$, higher than our value of $1.2 \mathrm{mmol} \mathrm{Si} / \mathrm{m}^{3}$ (MET). To test if this difference in 
Table 5

The effect of varying atmospheric iron inputs on global patterns of nutrient limitation during summer months (December-February in Southern Hemisphere and June-August in Northern Hemisphere) ${ }^{\mathrm{a}}$

\begin{tabular}{|c|c|c|c|c|c|c|c|c|c|c|c|c|}
\hline \multirow{2}{*}{$\begin{array}{l}\text { Atmospheric iron input } \\
(\% \text { Soluble })\end{array}$} & \multicolumn{5}{|c|}{ Diatoms } & \multicolumn{4}{|c|}{ Small phytoplankton } & \multicolumn{3}{|c|}{ Diazotrophs } \\
\hline & $\mathrm{N}$ & $\mathrm{Fe}$ & $\mathrm{Si}$ & $\mathrm{P}$ & Replete & $\mathrm{N}$ & $\mathrm{Fe}$ & $\mathrm{P}$ & Replete & $\mathrm{Fe}$ & $\mathrm{P}$ & Replete \\
\hline No Atmospheric Fe input & 30.1 & 61.6 & 7.7 & 0.57 & 0.02 & 15.1 & 83.9 & 0.99 & 0.02 & 54.2 & 0.42 & 45.3 \\
\hline \multicolumn{13}{|l|}{ Tegen and Fung (1995) } \\
\hline $2 \% \mathrm{~b}$ & 50.0 & 38.8 & 10.6 & 0.55 & 0.08 & 45.3 & 50.2 & 4.4 & 0.09 & 35.3 & 3.5 & 61.1 \\
\hline $4 \%$ & 55.4 & 31.0 & 12.9 & 0.63 & 0.02 & 53.9 & 40.1 & 6.0 & 0.02 & 23.0 & 5.1 & 71.9 \\
\hline $6 \%$ & 58.1 & 26.4 & 14.9 & 0.71 & 0.02 & 58.8 & 34.5 & 6.7 & 0.02 & 17.0 & 5.7 & 77.3 \\
\hline $10 \%$ & 62.4 & 21.1 & 15.6 & 0.89 & 0.02 & 64.8 & 26.2 & 9.0 & 0.03 & 10.6 & 6.9 & 82.5 \\
\hline \multicolumn{13}{|l|}{ Mahowald et al. (1999) } \\
\hline $2 \%$ & 44.2 & 45.2 & 10.0 & 0.61 & 0.02 & 34.4 & 62.0 & 3.5 & 0.04 & 41.4 & 3.7 & 55.0 \\
\hline $4 \%$ & 48.4 & 40.7 & 10.4 & 0.55 & 0.02 & 40.9 & 54.0 & 5.1 & 0.02 & 37.1 & 4.5 & 58.4 \\
\hline $6 \%$ & 50.4 & 38.0 & 11.0 & 0.56 & 0.02 & 44.6 & 49.5 & 5.9 & 0.04 & 33.8 & 5.0 & 61.1 \\
\hline $10 \%$ & 53.1 & 34.1 & 12.3 & 0.53 & 0.03 & 49.8 & 42.6 & 7.6 & 0.03 & 28.3 & 5.3 & 66.4 \\
\hline LGM $2 \%$ & 61.4 & 21.0 & 16.7 & 0.87 & 0.03 & 62.4 & 27.8 & 9.7 & 0.04 & 15.2 & 6.9 & 78.0 \\
\hline LGM $10 \%$ & 71.3 & 8.8 & 18.6 & 1.3 & 0.03 & 76.4 & 10.8 & 12.7 & 0.06 & 2.3 & 8.7 & 89.0 \\
\hline Saturating Atmospheric Fe & 77.3 & 0.01 & 21.5 & 0.94 & 0.20 & 83.6 & 0.15 & 15.9 & 0.41 & 0.05 & 9.0 & 90.9 \\
\hline \multicolumn{13}{|l|}{ Alternate model runs, TF $2 \%$} \\
\hline No Fe affect on Si quota & 50.8 & 43.1 & 5.5 & 0.60 & 0.03 & 45.5 & 49.9 & 4.6 & 0.03 & 35.5 & 3.5 & 61.0 \\
\hline $\mathrm{Ks}$ for $\mathrm{Si}=3.0 \mathrm{mmol} / \mathrm{m}^{3}$ & 49.2 & 37.0 & 12.9 & 0.49 & 0.02 & 46.0 & 49.5 & 4.6 & 0.02 & 35.3 & 3.7 & 61.0 \\
\hline No Atms. Si deposition & 50.0 & 38.7 & 10.8 & 0.54 & 0.03 & 45.8 & 49.8 & 4.4 & 0.02 & 35.3 & 3.5 & 61.2 \\
\hline No Diazotrophs & 51.3 & 37.9 & 10.3 & 0.48 & 0.02 & 47.7 & 48.1 & 4.3 & 0.03 & & & \\
\hline Fe quotas increased $25 \%$ & 47.5 & 41.9 & 10.1 & 5.4 & 0.03 & 41.7 & 54.6 & 3.7 & 0.03 & 40.0 & 3.1 & 56.8 \\
\hline
\end{tabular}

${ }^{a}$ Shown is the percentage of total ocean area where phytoplankton growth is limited by each nutrient (due to rounding may not add to 100). Nutrient replete areas are defined as regions where mean summer cell quotas for all nutrients are at least $97 \%$ of their maximum values (see text). The diazotrophs cannot be nitrogen limited. Results from several alternate model runs are also shown (see text for details).

${ }^{\mathrm{b}}$ Standard model run.

half-saturation constants would make a significant difference in nutrient-limitation patterns, we did an alternate model run with a half-saturation constant for Si uptake of $3 \mathrm{mmol} \mathrm{Si} / \mathrm{m}^{3}$. There was little effect on primary and export production and only a small increase Si-limited area (mainly in Subantarctic waters) (Tables 4 and 5). Patterns of iron and silica limitation in the equatorial Pacific in this alternate run were nearly identical to those shown in Fig. 8. Dunne et al. (1999) showed that data from US JGOFS EqPac survey cruise II used by Dugdale and Wilkerson (1998) was from a time of anomalously high subsurface nutrient values. They argued that iron was the most likely limiting nutrient for diatoms within the equatorial upwelling zone (Dunne et al., 1999). Our model results support this conclusion, although deficiencies in our forcing grid in this region suggest some caution. 


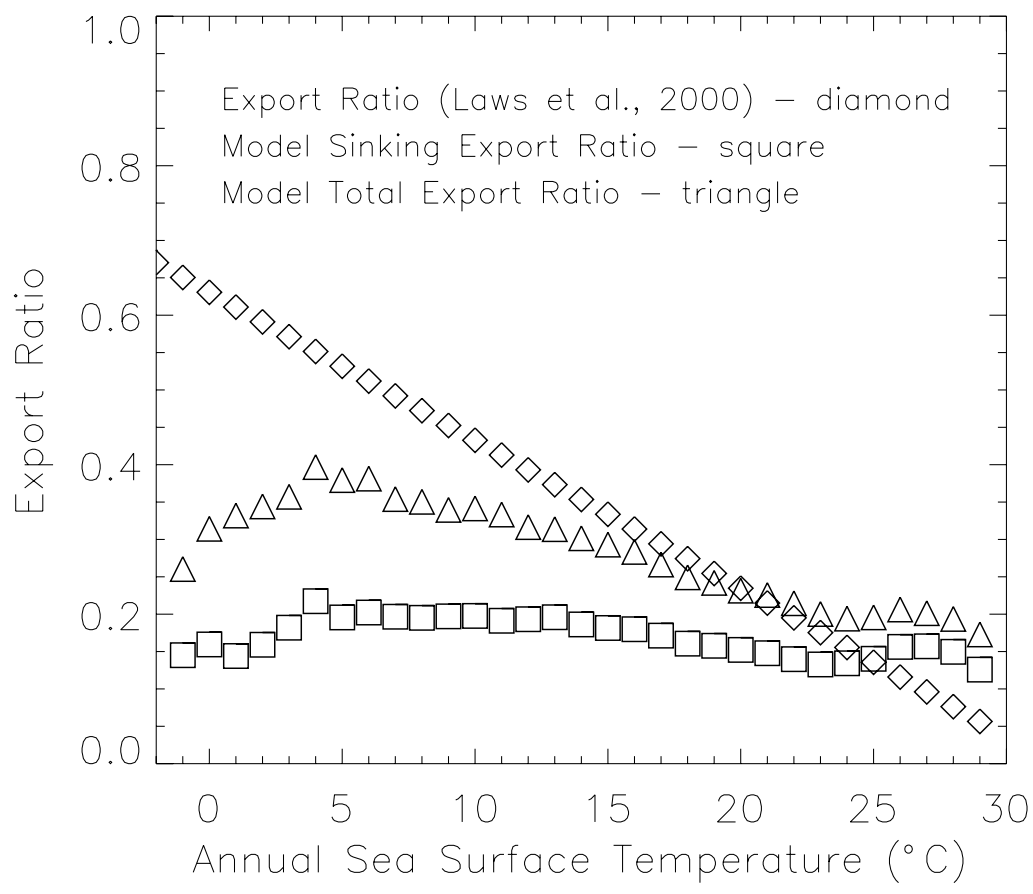

Fig. 13. The mean export ratio defined as the sinking POC flux/primary production (squares) and as total biogenic carbon export/primary production (triangles) as a function of annual mean sea-surface temperature (see text for details). Also shown for comparison is the temperature-export ratio relationship from Laws et al. (2000) (diamonds).

\subsection{Relationships between temperature and export production ratios}

The sinking flux of POC within the large detrital pool is largely a function of diatom production in the model (MET). Most material entering the diatom pool is eventually routed to the large detrital pool either directly through aggregation and non-grazing mortality or indirectly due to grazing (see MET). There are some sites with relatively low diatom production and elevated POC export. These are mainly high-latitude sites and coastal upwelling regions where the small phytoplankton bloom. At these sites carbon enters the large detrital pool mainly through aggregation of the small phytoplankton.

The average sinking export ratio (sinking POC flux/total production) and the total export ratio (sinking POC + export of biogenic carbon due to detrainment and turbulent mixing/total production) are shown in Fig. 13 as a function of annual mean sea-surface temperature (from the standard model run averaged over $1{ }^{\circ} \mathrm{C}$ bins). Also shown is the relation between temperature and export ratio from Laws et al. (2000). There is a strong temperature dependence for the total export ratio and a weak dependence for the sinking export ratio (Fig. 13). This largely reflects the fact that winter mixed-layer depths are deeper at high latitudes (cooler temperatures), thus large amounts of biogenic carbon are lost from the mixed layer due to detrainment and mixing in these regions. The different methods of export counterbalance to some extent as areas with low sinking 
export build up more material in the small detrital pool, some of which is subsequently lost to the mixed layer through detrainment and mixing.

There are some strong regional differences that go into the mean export ratio values seen in Fig. 13. In the mean annual temperature range from $0^{\circ} \mathrm{C}$ to $10^{\circ} \mathrm{C}$, nearly all Southern Ocean sinking export ratios (from $>40^{\circ} \mathrm{S}$ ) are between 0.1 and 0.15 , well below the mean values seen in Fig. 13. In contrast, over this same temperature range nearly all of Northern Hemisphere sites (from $>40^{\circ} \mathrm{N}$ ) have sinking export ratios at or above the mean value, ranging from 0.2 to 0.5 . This pattern is driven by strong iron limitation over most of the Southern Ocean.

The temperature relationship of Laws et al. (2000) was based on data from eleven in-situ studies. They found a strong correlation between export ratio and mean temperature (accounting for $86 \%$ of the variance in export ratios, Laws et al., 2000). This high correlation was somewhat fortuitous as the coldest sites used in the study (Ross Sea and the Northeast Water polynya near Greenland) were high export, nutrient-replete sites. There are many cold-water sites (particularly in the Southern Ocean) with relatively low export ratios. Laws et al. (2000) noted that using their temperature relationship alone greatly overpredicted export over much of the Southern Ocean. Their relation based on total production and temperature did much better at high Southern Hemisphere latitudes (Laws et al., 2000). Laws et al. (2000) assumed that all export was due to sinking particles. However, their model was validated with field data from in-situ locations where the $f$-ratio was typically estimated based on nitrate uptake. The field data would thus include all modes of export, including detrainment and mixing.

\subsection{Primary production, particulate organic carbon export, and atmospheric iron deposition}

We next examine the sensitivity of the marine ecosystem to variations in the atmospheric iron deposition. We present results from model runs identical to the standard run except for variations in the atmospheric iron source. First we examine the extreme cases of no atmospheric iron input and a saturating iron input from the atmosphere (Fig. 14). For the saturating iron deposition we increased the atmospheric source until iron was essentially no longer a limiting nutrient. There is a drastic difference in primary production in the two model runs, from $35 \mathrm{Gt} \mathrm{C}$ with no atmospheric iron input to $70.5 \mathrm{Gt} \mathrm{C}$ with saturating input (Fig. 14). The increases at higher atmospheric iron flux are seen mainly in the HNLC regions of the Southern Ocean, the subarctic North Pacific, and the Equatorial Pacific, with large increases also in most upwelling areas (Fig. 14). The POC export within the sinking large detrital pool in the two runs was $5.8 \mathrm{Gt} \mathrm{C}$ and $16.5 \mathrm{Gt} \mathrm{C}$, respectively. These differences in primary and export production are conservative estimates of the extreme cases because the subsurface iron source has been held constant in both runs. Drastic changes in the atmospheric iron flux would alter subsurface iron concentrations over time and increase the differences primary and export production.

Primary production, sinking POC export, the sinking export ratio, and total nitrogen fixation from a number of model runs with different atmospheric Fe depositions and solubilities are summarized in Table 4. Both primary production and export production increase with increasing atmospheric iron inputs (Table 4). Export production increases more rapidly than total production, thus the ratio of export/total production also increases with increasing atmospheric iron inputs (Table 4). This is because some areas are shifting from a low-export, low-biomass regime dominated by small phytoplankton to one in which diatoms dominate with correspond- 


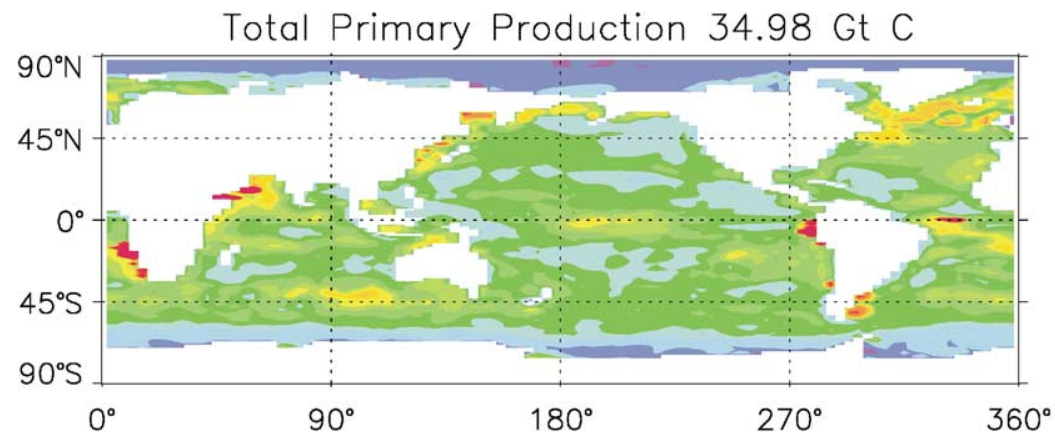

A) Mixed Layer Primary Production, No Atmospheric Iron Input
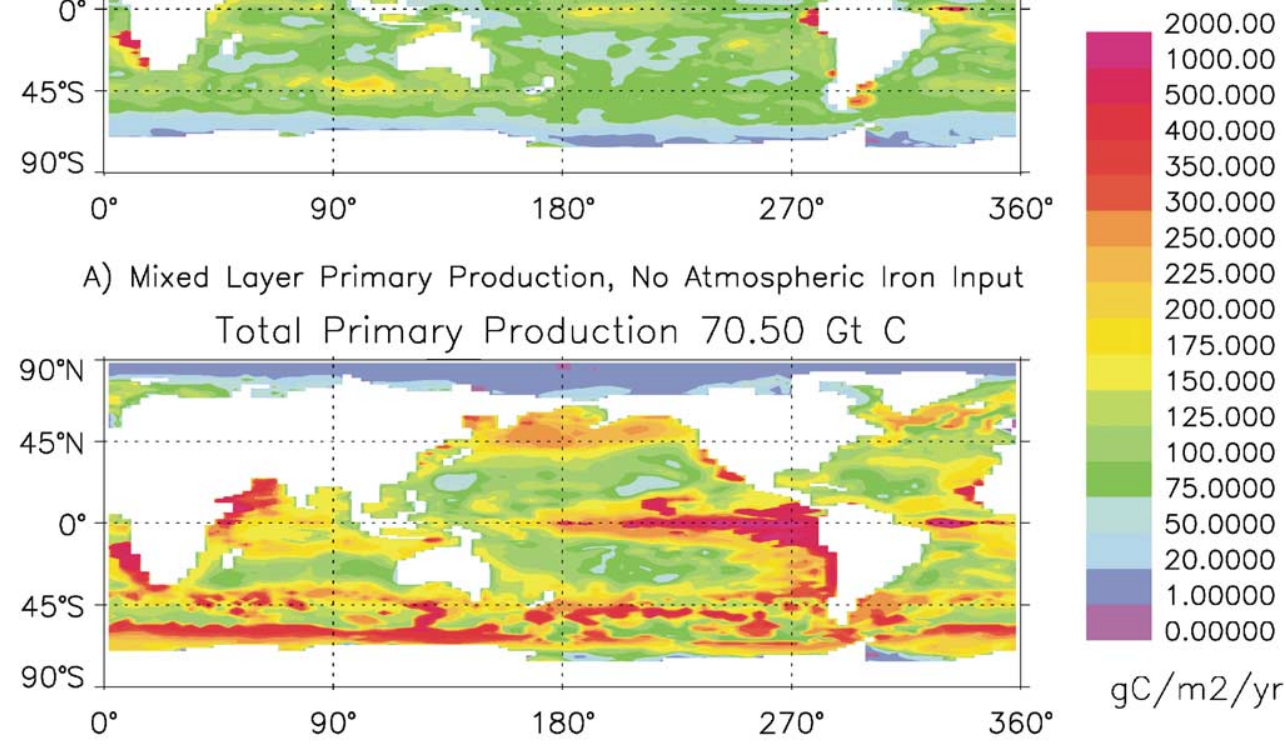

B) Mixed Layer Primary Production, Saturating Atmospheric Iron Input

Fig. 14. Displayed is the annual mixed layer primary production from the ecosystem model with no atmospheric iron deposition (A) and with a saturating atmospheric iron deposition (B).

ingly higher export. Since deposition to the open ocean Fe-limited areas is generally lower in MAH99 (see Fig. 1), increasing the solubility has less of an effect on total and export production than with TF95 (Table 4). Thus, increasing solubility of TF95 deposition from 2\% to $10 \%$ increases total production from 45.2 to $56.1 \mathrm{Gt} \mathrm{C}(24 \%$ increase), while the same increase in solubility with the MAH99 deposition increases production from 42.1 to $47.0 \mathrm{Gt} \mathrm{C}$ (12\% increase) (Table 4).

We convert the MAH99 LGM dust flux to iron flux assuming as before dust is 3.5\% iron by weight. Total LGM iron deposition to the oceans is then $2.12 \times 10^{12} \mathrm{~mol} \mathrm{Fe} / \mathrm{yr}$, higher than the modern day flux of MAH99 by a factor of 4.6. MAH99 noted that the estimated LGM total global dust loading to the atmosphere increased by a factor of 2.5 with 20 -fold increases at high latitudes. We present results from two runs (2\% and $10 \%$ solubility) in Table 4 where the model was forced with these LGM iron depositions. Primary and export production in the model run with LGM atmospheric iron inputs at $10 \%$ solubility are nearly as high as in the Fe-replete run (Table 4). These are not full simulations of the LGM, as we still use the modern day mixed-layer depths, sea-surface temperature, etc. However, they do illustrate a strong sensitivity to the estimated differences in atmospheric iron deposition. 


\subsection{Global scale nutrient-limitation patterns and atmospheric iron deposition}

Next we examine how variations in atmospheric iron input affect the summertime nutrientlimitation patterns. Table 5 summarizes the area of each nutrient-limitation regime for each of the model runs listed in Table 4. For the diatoms, increasing the atmospheric iron inputs leads to more areas becoming either $\mathrm{N}$ - or Si-limited, while the nutrient-replete regions are always $\ll 1 \%$ of total ocean area (Table 5). For the small phytoplankton the areas which are N- and P-limited both steadily increase as atmospheric iron input increases (Table 5). Note that even with the high LGM dust deposition from MAH99 there are still substantial Fe-limited regions during summer months (Table 5). The diazotrophs are Fe-limited over $54 \%$ of the ocean with no atmospheric iron deposition, and over $41 \%$ with the MAH99 deposition at 2\% solubility. The Fe-limited area steadily decreases with increasing atmospheric iron deposition as with the other phytoplankton (Table 5). Up to $9 \%$ of the world ocean is P-limited for the diazotrophs (Table 5).

In the saturating atmospheric iron deposition run some interesting nutrient-limitation patterns result. The equatorial upwelling band in the Pacific, the Arabian Sea, most Subantarctic waters, and much of the high-latitude North Atlantic become Si-limited for the diatoms. Areas north and south of the equatorial upwelling band in the Pacific become N-limited. At high southern latitudes the diatoms are either Si- or N-limited. The high-latitude north Pacific Ocean becomes N-limited for the diatoms and the small phytoplankton. For the small phytoplankton in the Southern Ocean, Subantarctic waters are either $\mathrm{N}$ - or P-limited and the highest latitudes are mainly Nlimited. Similarly, in the equatorial Pacific, the small phytoplankton are typically N-limited in the strong upwelling band with waters to the north and south being either P- or N-limited. Portions of the northern Indian Ocean and much of the high-latitude North Atlantic are P-limited for the small phytoplankton. The diazotroph P-limited areas expand somewhat, particularly in the eastern tropical Pacific, but the primary controls on biomass remain light and temperature (Table 5).

The saturating iron input case is not realistic in the level of dust fluxes and is presented as an upper limit. The next highest atmospheric flux we examine is the MAH99 LGM flux with a solubility of $10 \%$. There is very high production and export in the HNLC regions in this run. However, even at these very high atmospheric iron inputs, the Southern Ocean (latitudes $>45^{\circ} \mathrm{S}$ ) is Fe-limited during summer months, except in the Atlantic sector where there is little $\mathrm{Fe}$ limitation. Significant portions of the equatorial Pacific are also Fe-limited for the diatoms and small phytoplankton. A small portion of the North Atlantic is Fe-limited for the small phytoplankton. The subarctic North Pacific becomes N-limited for the small phytoplankton and either Si- or N-limited for the diatoms. The diazotrophs are essentially Fe-replete in this run (Table 5).

We use a $2 \%$ solubility as a best guess value in our standard run based on the analysis of Fung et al. (2000) and the review of Jickells and Spokes (in press). Archer and Johnson (2000) noted that a $2 \%$ solubility (with TF95) best reproduced observed phosphate distributions in their model (6\% solubility with MAH99). Note that in our standard run at $2 \%$ solubility, the small phytoplankton are Fe-limited over $>50 \%$ of the world ocean and the diatoms are either Fe- or Silimited over $>49 \%$ of the world ocean (Table 5). The Fe-limited areas are larger with the MAH99 iron deposition (Table 5). In addition, the diazotrophs are Fe-limited in many areas where the diatoms and small phytoplankton are N-limited (19\% of the world ocean in our standard run). 
Thus, nitrogen which is classically thought to be the key limiting nutrient in the oceans is controlling phytoplankton growth rates over less than half of the world ocean. There is a strong sensitivity to the atmospheric deposition, particularly in the transition zones between macronutrient- and Fe-limited regions (compare the Fe- and N- limited regions with the TF95 dust flux at $2 \%$ and $4 \%$ solubilities, Table 5).

We did an alternate run of the model with no diazotrophs and thus no nitrogen fixation. There was a modest decrease in global primary and export production without the diazotrophs (Table 4). In addition, the $\mathrm{N}$-limited areas during summer months increased by $2.6 \%$ for the diatoms and by $5.3 \%$ for the small phytoplankton relative to our standard model run (Table 5). In a separate sensitivity experiment, we increased the maximum cellular Fe quota by $25 \%$ for all three phytoplankton classes. This decreased global primary production by $\sim 3 \mathrm{Gt} \mathrm{C}$ and the sinking export flux by $0.6 \mathrm{Gt} \mathrm{C} \mathrm{(Table} \mathrm{4).} \mathrm{The} \mathrm{area} \mathrm{Fe-limited} \mathrm{during} \mathrm{summer} \mathrm{months} \mathrm{expanded}$ by $3.1 \%$ for the diatoms, by $4.4 \%$ for the small phytoplankton, and by $4.7 \%$ for the diazotrophs. Global nitrogen fixation decreased to $56.0 \mathrm{Tg} \mathrm{N} / \mathrm{yr}(10 \%$ decrease from the standard run). This indicates a moderate sensitivity to the maximum iron quotas. We believe the Fe quotas chosen for our standard run are appropriate values for use in a global model.

\section{Discussion}

The ecosystem model accurately reproduces strong Fe limitation of phytoplankton growth rates and community structure in the HNLC regions. At an assumed $2 \%$ solubility for the atmospheric iron source, the model predicts realistic global patterns of primary production, biogenic silica production, $\mathrm{N}$-fixation, $\mathrm{CaCO}_{3}$ export, $\mathrm{POC}$ export, and surface chlorophyll concentrations. The model results are also in good agreement with the limited field observations of phytoplankton cellular $\mathrm{Fe} / \mathrm{C}$ ratios, and surface dissolved iron and nitrate concentrations.

Model estimates of dissolved iron concentrations tend to be lower than in-situ measurements. This may imply that a significant portion of the dissolved Fe measured in situ is not readily available for phytoplankton uptake. Alternatively, there may be weaknesses in the model, for example half-saturation uptake values for iron may be set too low, or there may be important regional differences in the iron physiology of phytoplankton not captured by our global formulation, or the model may be missing important sources of dissolved Fe, perhaps from the particulate pool which we neglect. These results illustrate a pressing need for more in-situ measurements of dissolved $\mathrm{Fe}$ and its relation to phytoplankton growth rates and physiology. Depth resolved fields of dissolved $\mathrm{Fe}$ also are desperately needed for model initialization.

The largest differences between in-situ and satellite observations and the model output are seen in areas where there are deficiencies in the mixed-layer grid formulation. The model under predicts phytoplankton biomass and production in equatorial upwelling regions where lateral advection is important. The mixed-layer formulation used here also does not account for processes occurring over the entire euphotic zone, including production at the deep chlorophyll maximum (DCM). Significant portions of the sinking export flux may be produced in the DCM (Goldman, 1993). The ecosystem model is currently being incorporated into the 3D NCAR Climate Ocean Model. This will provide better physical forcings particularly in equatorial regions, incorporate the entire 
euphotic zone, and allow coupled climate simulations of land, sea, and atmospheric processes including the production, transport, and deposition of dust.

Global scale patterns of nutrient limitation and primary and export production are sensitive to variations in atmospheric iron inputs to surface waters (Tables 4 and 5). Our results suggest that Fe-limited regions of the world ocean equal or exceed N-limited areas (Fig. 8, Table 5). This is true across a range of assumed dust-iron solubilities using either the TF95 or MAH99 deposition estimates (Table 5). Thus Fe inputs (from above and below) are likely as important as subsurface nitrate inputs in controlling new production rates at the global scale as suggested by Martin et al. (1989).

Archer and Johnson (2000) argued that most export production (70-80\%) in the oceans today could be supported by subsurface Fe sources. Our model results support this conclusion since with no atmospheric Fe input, primary production and export production were $77 \%$ and $73 \%$ of the values from our standard model run (Table 4). This may be misleading however as subsurface $\mathrm{Fe}$ is ultimately dependent on the atmospheric inputs. Archer and Johnson (2000) also noted in their model that when atmospheric Fe deposition fell below a critical threshold, export production rapidly and drastically decreased as subsurface Fe concentrations were depleted. Our results suggest that roughly $50 \%$ of the world ocean is Fe-limited at the present time, and thus variations in atmospheric inputs will lead directly to changes in export production. In addition, relatively small changes in $\mathrm{Fe}$ input can shift community structure from one dominated by small phytoplankton to one dominated by diatoms, which sharply increases the sinking POC flux and thus carbon export to the deep ocean. The atmospheric Fe inputs thus have a critical impact on ocean biota and carbon cycling at the global scale. Better estimates of the atmospheric deposition and its variability over all time scales are needed in order to understand how changing climate conditions interact with biogeochemical cycling in the oceans.

The model results indicate that Fe limitation should be an important factor in the traditional HNLC regions of the northeast subarctic Pacific, the equatorial Pacific, and the Southern Ocean. The model also expands this Fe-limited domain to include the northwest subarctic Pacific, the eastern South Pacific Gyre, some equatorial areas in the Atlantic and Indian oceans, and parts of the North Atlantic (Fig. 8). The transition zones between the mid-ocean gyres and the HNLC regions also tend to be Fe limited. These transition zones shift from $\mathrm{Fe}$ to $\mathrm{N}$ limitation as atmospheric iron deposition increases (Table 5). There is evidence for Fe limitation in some of these areas. Behrenfeld and Kolber (1999) found good evidence for Fe stress in macronutrientdepleted waters of the eastern South Pacific Gyre. Our results are consistent with this finding and suggest that Fe may be limiting growth rates, particularly in the eastern portion of the gyre where atmospheric dust inputs are very low (Fig. 1). DiTullio et al. (1993) found that diatoms were colimited by $\mathrm{Fe}$ and macronutrients in oligotrophic waters of the North Pacific in the transition zone between the gyre and equator. We are unaware of studies testing for Fe limitation in the equatorial zones of the Atlantic or Indian Oceans. Lateral advection of iron (not included in our model) may prevent Fe limitation in some of these regions. However, Fe limitation also may occur, particularly south of the equator where dust inputs are significantly lower (see Fig. 1). The atmospheric $\mathrm{Fe}$ source accounts for $<30 \%$ of total inputs in portions of the equatorial Atlantic and Indian Oceans, mainly south of the equator (Fig. 10). The northwest subarctic Pacific and the high latitude North Atlantic are not generally considered to be Fe-limited regions. However, some Fe limitation may occur in these regions, particularly in late summer. 
Our model results indicate that the primary control on rates of $\mathrm{N}$ fixation in tropical and subtropical regions is mixed-layer depth through its influence on light and temperature. As diazotrophs have a low initial slope of the P vs. I curve, slow maximum growth rates, and relatively high respiration losses, significant biomass accumulations only occur in regions with relatively shallow mixed layers. This is consistent with the results from some field studies (Karl et al., 1995; Hansell and Feely, 2000). However, when favorable light and temperature conditions do allow for significant increases in diazotroph biomass, ambient dissolved iron is rapidly depleted and $\mathrm{N}$ fixation and diazotroph growth rates become limited by Fe. This supports the suggestion in recent years that $\mathrm{Fe}$ availability (and dust deposition) plays a major role determining diazotroph growth rates and $\mathrm{N}$ fixation rates in the oceans today (Raven., 1988; Reuter et al., 1992; Falkowski, 1997). Recent theoretical estimates and laboratory experiments examining the iron requirements of Trichodesmium suggest that earlier studies which suggested that the Fe requirements of diazotrophs are up to 100 times higher than other phytoplankton (Raven., 1988; Reuter et al., 1992), overestimated the likely influence of Fe limitation (Kustka et al, submitted; Ilana Berman-Frank, Jay Cullen, Yaeila Hareli and Paul Falkowski, pers. comm.). We have set the Fe quota for the diazotrophs only 8-fold higher than the other phytoplankton based on these two studies, and we still see a strong impact of $\mathrm{Fe}$ dynamics on $\mathrm{N}$ fixation at the global scale.

Bruland et al. (1994) found a strong surface mixed-layer maximum in dissolved $\mathrm{Fe}$ concentrations in the central North Pacific gyre due to the dominance of the atmospheric source for iron. Iron was strongly depleted beneath the surface mixed layer, within the euphotic zone (Bruland et al., 1994). Given the dominance of the atmospheric Fe source in the mid-ocean gyre regions (Fig. 10), this pattern is likely a common one. Trichodesmium often displays a biomass maximum just below the surface mixed layer in the North Pacific (Letelier and Karl, 1996). Thus, it is possible that the diazotrophs would be Fe-limited beneath the surface mixed layer, even in areas where there was sufficient iron in surface waters. Given its subsurface source, phosphate is likely to be more depleted in the surface mixed layer. Thus, one can envision a smallscale vertical migration for Trichodesmium spp. whereby $\mathrm{Fe}$ is taken up in the surface mixed layer and phosphate is taken up in waters beneath the surface mixed layer at intermediate depths, but shallower than the phosphocline.

The diazotrophs accounted for a total $0.22 \mathrm{Gt} \mathrm{C}$ of primary production $<1 \%$ of the total (Table 3). In the alternate model run without the diazotroph phytoplankton class, total primary production decreased by $1.5 \mathrm{Gt} \mathrm{C}$ (Table 4). Thus, the presence of the diazotrophs increases primary production by the diatoms and small phytoplankton by $1.28 \mathrm{Gt} \mathrm{C}$, mainly through the excretion of DON in N-limited areas. The sinking export flux declined by $0.26 \mathrm{Gt} \mathrm{C}(3.3 \%$ decrease) without the diazotroph phytoplankton class (Table 4). The difference in export is mainly due to the stimulatory effect the diazotrophs have on the diatoms, as the diazotrophs can only enter the sinking pool indirectly through grazing processes (see MET). Total grazing on diazotrophs was $0.05 \mathrm{Gt} \mathrm{C}$ and approximately $33 \%$ of this would eventually end up the sinking detrital pool (see MET). While at the global scale the impact of the diazotrophs on carbon fluxes was modest, regionally the diazotrophs can have a very strong influence. For example in the alternate run without the diazotrophs, primary production was reduced by $40 \%$, sinking POC export by $\sim 50 \%$, and chlorophyll concentrations by $\sim 50 \%$ relative to the standard run at the HOT location. 


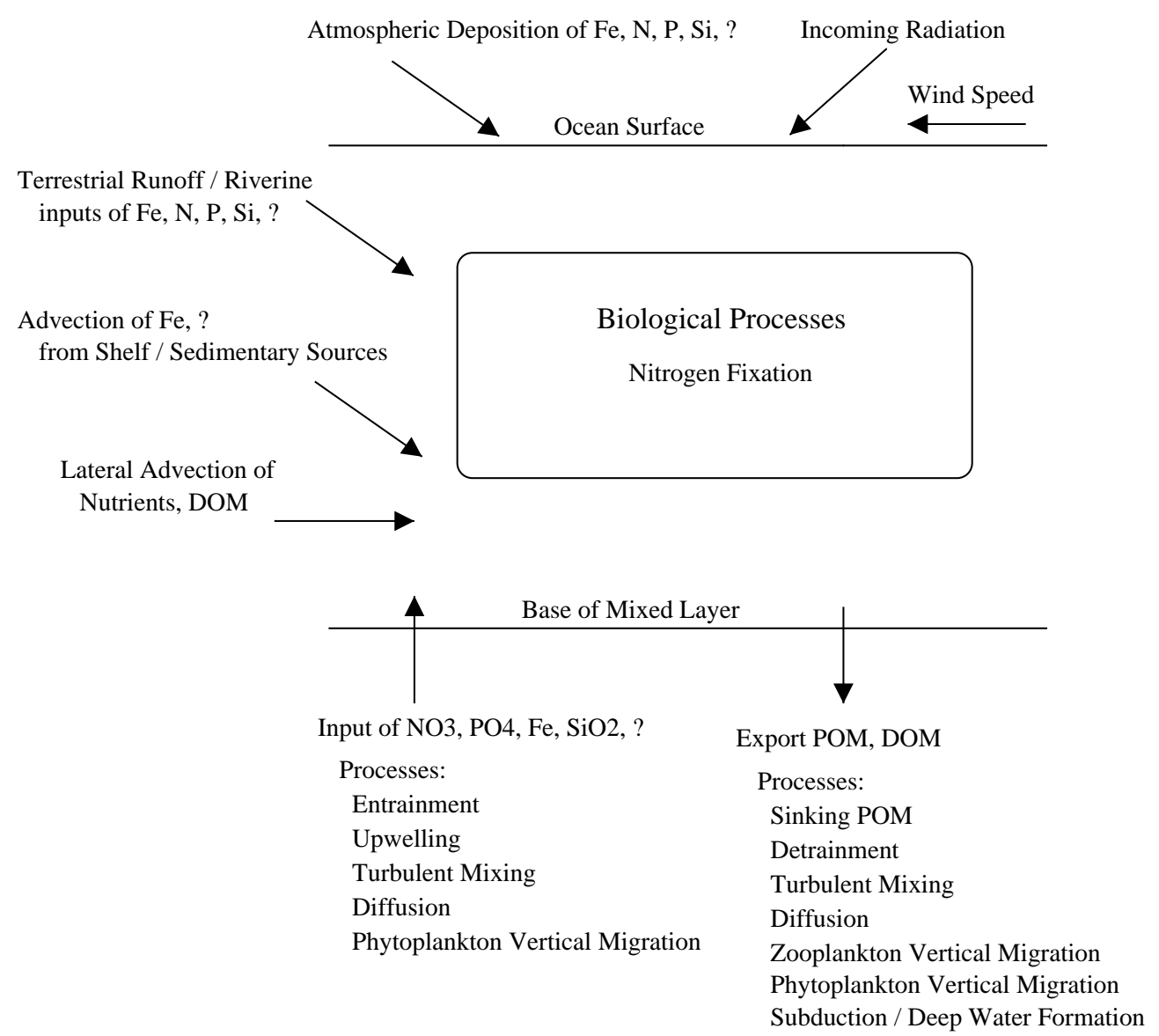

Fig. 15. A schematic depicting the multiple controls on export production in the global ocean and describing the multiple modes of carbon export.

The export of carbon from the surface mixed layer in the model is dominated by the sinking particulate flux (Table 3). However, detrainment and mixing processes also account for a significant fraction of export (Table 3, Fig. 7). Much of the carbon export due to detrainment and mixing would be remineralized at fairly shallow depths (less than a few hundred meters) and likely entrained again the following spring. The same can be said of the sinking flux, however, as most of it is remineralized in the upper few hundred meters of the water column. Even so, carbon flux to the deep ocean would be due almost exclusively to the sinking flux.

In their seminal paper, Eppley and Peterson (1979) argued that export production in the oceans was largely controlled by the input of subsurface nitrate to the surface layer and that the sinking of particulate organic matter was the primary export mechanism. The model results presented here, in conjunction with other recent studies, suggest that the new production model of Eppley and Peterson (1979) needs to be expanded to include multiple limiting nutrients and multiple modes of carbon export. 
A large number of studies over the last decade (many as part of the IronEx or JGOFS studies) have demonstrated that iron inputs (from above and below) control export production over large portions of the world ocean (Martin et al., 1989, 1991; Helbling et al., 1991; Martin, 1992; Price et al., 1994; de Baar et al., 1995; Coale et al., 1996; Landry et al., 1997; Behrenfeld and Kolber, 1999; Boyd and Harrison, 1999; Moore et al., 2000; and references cited in these papers). Iron can limit export even in coastal upwelling systems (Hutchins et al., 1998).

Silica was also an important limiting nutrient in our model results, and there is considerable evidence for Si limitation in many regions (Nelson and Tréguer, 1992; Sieracki et al., 1993; Dugdale et al., 1995; Dugdale and Wilkerson, 1998; Boyd et al., 1999; Abbott et al., 2000; Nelson et al., 2001). Our model may in fact underestimate the extent of Si limitation in the high-latitude Southern Ocean where very high half-saturation constants for Si uptake $(>20 \mu \mathrm{M})$ are sometimes observed (Nelson et al., 2001). Phosphate was the limiting nutrient over $\sim 4 \%$ of the oceans for the diazotrophs and the small phytoplankton group in our standard run (Table 5). P limitation would be sensitive to the rates of $\mathrm{N}$ fixation, and there may be shifts between $\mathrm{N}$ and $\mathrm{P}$ limitation over long timescales (Falkowski, 1997). This nutrient list is not exhaustive as other trace elements such as zinc may limit phytoplankton growth (Morel et al., 1994).

In addition, there may be co-limitation by Fe-light, Fe-Si, or Fe-macronutrients in a number of regions (DiTullio et al., 1993; Takeda et al., 1995; Boyd et al., 1999; Maldonado et al., 1999; Abbott et al., 2000). DiTullio et al. (1993) found that additions of macronutrients and Fe produced the greatest biological response in oligotrophic waters in the North Pacific. Similarly Takeda et al. (1995) found that additions of nitrate and iron produced the greatest biomass increases in the northwestern Indian Ocean. Seasonal shifts and variations in these patterns are also likely (Boyd et al., 1999; Maldonado et al., 1999; Abbott et al., 2000). In our model results the stronger depletion of ambient silicate levels due to iron stress led to Si limitation later in the season over $\sim 4.3 \%$ of the world ocean.

Eppley and Peterson (1979) excluded polar areas from their analysis and suggested that dissolved organic matter exported through mixing processes accounted for a small percentage of total export $(\sim 2-15 \%)$. This number likely needs to be revised upwards. Our results suggest that this can be the dominant export mechanism in some areas that are strongly nutrient-limited with low primary production (where diatom production is minimal), particularly at high latitudes.

Controls on export production and modes of export are summarized in Fig. 15. Globally the dominant controls on export production are suggested to be nitrate inputs from below and iron inputs (from subsurface and atmospheric sources) in largely spatially distinct regions. A number of other less significant sources for $\mathrm{N}$ and $\mathrm{Fe}$ as well as other potentially limiting nutrients are also depicted (Fig. 15). Nitrogen inputs due to $\mathrm{N}_{2}$ fixation by the biota may exceed inputs from subsurface sources in tropical regions (Capone et al., 1997; Karl et al., 1997). Phosphorus and silica may also be the limiting nutrient for export production in some regions (Karl et al., 1997; Dugdale et al., 1995; Nelson et al., 2001).

Atmospheric deposition of $\mathrm{N}$ and $\mathrm{P}$ to the open ocean is generally a small fraction of the input from subsurface sources (Duce, 1986; Duce et al., 1991). However, in coastal waters this deposition can be a significant source of new nutrients, particularly in anthropogenically influenced regions (Duce, 1986, 1991). Even in open ocean areas the atmospheric inputs may be significant over short time periods (i.e. for a period of a few days following a rain event in heavily stratified mid-ocean gyre regions) (Duce, 1986; Duce et al., 1991). Terrestrial runoff and riverine 
inputs as well as shallow water sedimentary sources for iron are likely important mainly in coastal regions. Iron is not transported far off shore in surface waters, although the subsurface signal from sedimentary continental shelf sources may travel long distances (Johnson et al., 1997; Luther and $\mathrm{Wu}, 1997)$.

We include question marks in Fig. 15 to represent other potentially limiting nutrients (such as zinc) that may affect export production sporadically or only for certain phytoplankton species or groups. Co-limitation between light and these key nutrients is also a possibility (particularly ironlight co-limitation, Sunda and Huntsman, 1997; Boyd et al., 1999; Maldonado et al., 1999). Light availability controls export production at high latitudes during winter months and may also be important during spring and fall where mixed layers are deep (as frequently happens in the Southern Ocean). In addition light inputs can vary significantly over time through changes in cloud cover patterns. Mixed-layer depth also influences the light environment experienced by phytoplankton and the input of subsurface nutrients. Thus, wind speed and buoyancy can be additional controls on export production through their influence on mixed-layer depths. In addition to the physical processes listed in Fig. 15, active vertical migration by large phytoplankton species can be an additional route for subsurface nutrients to move into the surface layer (Villareal et al., 1993, 1996, 1999).

Sinking of particulate matter dominates export production at the global scale. The mixing processes including detrainment listed in Fig. 15 export both particulate and dissolved organic matter from the surface layer. Our model results suggest that in some regions these modes of export can exceed the sinking flux. In the Sargasso Sea the sinking flux of particulate matter seems insufficient to account for most carbon export, and export of dissolved organic carbon during deep winter mixing is an important export component (Michaels et al., 1994; Carlson et al., 1994). Vertical migration by zooplankton and phytoplankton also can be a significant mechanism for export of carbon from surface waters (Longhurst et al., 1990; Richardson et al., 1998).

The strong sensitivity of export production to atmospheric iron inputs seen in the model output supports the Iron Hypothesis of Martin and coworkers for a biological role in the drawdown of atmospheric carbon dioxide levels during the last ice age (Martin et al., 1989; Martin, 1990). Global export production increases substantially (by $41 \%$ and $55 \%$, at $2 \%$ solubility) when the model is forced with the LGM dust fluxes of MAH99 compared to the modern day fluxes using MAH99 or TF95 (Table 4). Much of the increase is in the Southern Ocean, where sinking export (at latitudes $\left.>30^{\circ} \mathrm{S}\right)$ in the modern ocean is 1.5 and $1.8 \mathrm{Gt} \mathrm{C} \mathrm{(2 \%} \mathrm{solubility)} \mathrm{and} 1.9$ and $2.7 \mathrm{Gt} \mathrm{C}$ (10\% solubility, with the MAH99 and TF95 dust forcings, respectively), while with the LGM dust flux, export is $3.0 \mathrm{Gt} \mathrm{C} \mathrm{(2 \%} \mathrm{solubility)} \mathrm{and} 4.9 \mathrm{Gt} \mathrm{C}(10 \%$ solubility). The increase in sinking export production in response to the glacial dust flux thus ranges from $1.2-1.5 \mathrm{Gt} \mathrm{C}(2 \%$ solubility) to $2.2-3.0 \mathrm{Gt} \mathrm{C}(10 \%$ solubility), which would include only export from the surface mixed layer. This is somewhat less than the estimate of Moore et al. (2000) of a LGM increase in total export production for this region of 2.9-3.6 Gt $\mathrm{C}$ based on an extrapolation of modern day measurements. Moore et al. (2000) assumed that the LGM dust fluxes would completely alleviate Fe limitation in the Southern Ocean. Our model results, however, indicate that much of the Indian and Pacific sectors of the Southern Ocean would still become Fe-limited during summer months, even with the much higher LGM dust fluxes. In the Fe-saturated model run, Southern Ocean export increased to 5.6 Gt C, which would represent an increase of 2.9-4.1 Gt C over the modern day export. While forcing the ecosystem model with glacial atmospheric Fe deposition but 
modern day sea-surface temperatures, mixed-layer depths, and surface radiation fields does not constitute a full LGM simulation, it does illustrate a very strong sensitivity to the estimated increase in atmospheric iron deposition.

Harrison (2000) recently proposed that atmospheric Si deposition played a strong role in glacial-interglacial productivity, and that the increased $\mathrm{Si}$ deposition during glacial times increased diatom export enough to account for the glacial atmospheric $\mathrm{CO}_{2}$ drawdown. In general, our results do not support this hypothesis. Harrison (2000) assumed that $\mathrm{Si}$ was the limiting nutrient for diatoms in the oceans today and that higher Si deposition during glacial times would translate directly into increased diatom (and decreased coccolithophore) production. Our results suggest that iron is the more important limiting nutrient for the diatoms in the ocean today (Table 5). In our standard run diatoms were Fe-limited over $38.8 \%$ of the world ocean during summer months and Si-limited over 10.6\% (Table 5). Roughly half of the Si-limited regions were a result of Fe stress, which increased the drawdown of ambient silicate concentrations. It should be noted that atmospheric $\mathrm{Si}$ deposition varied in our model runs with the dust model source (solubility was always $7.5 \%$ ), so in our model runs forced with the LGM dust deposition of MAH99 atmospheric Si deposition also increased to the estimated glacial levels. The total area where the diatoms were Si-limited increased when forced with the glacial dust flux while the Felimited areas decreased (Table 5). This is because the amount of Si in dust is relatively small compared to the amount of $\mathrm{Fe}$, when considered in relation to the elemental requirements of diatoms. Because the atmospheric source of dissolved silicate is negligible compared to subsurface sources in most regions, global patterns of primary and export production were nearly identical to our standard model run in an alternate run with no atmospheric Si deposition (Table 4). These results suggest that the impact of the glacial increase in atmospheric Si deposition on oceanic carbon fluxes was small compared to the impact of the increased iron deposition.

\section{Acknowledgements}

The authors thank Natalie Mahowald for providing the modern and LGM dust fluxes from Mahowald et al. (1999), the SeaWiFS project (Code 970.2) and the Distributed Active Archive Center (Code 902) at the Goddard Space Flight Center, Greenbelt, MD 20771, for the production and distribution of the ocean color data, respectively, and the National Snow and Ice Data Center for the satellite sea ice cover data. We also thank Ed Laws, Rob Armstrong, and an anonymous reviewer for their insightful comments and suggestions. This work was supported in part by NASA grants W-19,223 and NAG-5-6456, by NOAA grant NA96GP0360, and by the National Center for Atmospheric Research. The National Center for Atmospheric Research is sponsored by the National Science Foundation. This paper is US JGOFS contribution number 607.

\section{References}

Abbott, M.R., Richman, J.G., Bartlett, J.S., 2000. A mesoscale array of bio-optical sensors in the Antarctic polar front zone. Deep-Sea Research II 47, 3285-3314.

Archer, D.E., Johnson, K., 2000. A model of the iron cycle in the ocean. Global Biogeochemical Cycles 14, 269-279. 
Balch, W.M., Kilpatrick, K., 1996. Calcification rates in the equatorial pacific along $140^{\circ}$ W. Deep-Sea Research II 43, 971-993.

Barbeau, K., Moffett, J.W., Caron, D.A., Croot, P.L., Erdner, D.L., 1996. Role of protozoan grazing in relieving iron limitation of phytoplankton. Nature 380, 61-64.

Behrenfeld, M.J., Falkowski, P., 1997. Photosynthetic rates derived from satellite-based chlorophyll concentration. Limnology and Oceanography 42, 1-20.

Behrenfeld, M.J., Kolber, Z.S., 1999. Widespread iron limitation of phytoplankton in the south pacific ocean. Science $283,840-843$.

Bishop, J.K.B., Rossow, W.B., 1991. Spatial and temporal variability of global surface solar irradiance. Journal of Geophysical Research 96, 16839-16858.

Boyd, P., Harrison, P.J., 1999. Phytoplankton dynamics in the NE subarctic Pacific. Deep-Sea Research II 46, 2405-2432.

Boyd, P., LaRoche, J., Gall, M., Frew, R., McKay, R.M.L., 1999. Role of iron, light, and silicate in controlling algal biomass in subantarctic waters SE of New Zealand. Journal of Geophysical Research 104, 13 395-13408.

Brown, C.W., Yoder, J.A., 1994. Coccolithophorid blooms in the global ocean. Journal of Geophysical Research 99, 7467-7482.

Bruland, K.W., Orians, K.J., Cowen, J.P., 1994. Reactive trace metals in the stratified North Pacific. Geochimica et Cosmochimica Acta 58, 3171-3182.

Brzezinski, M.A., 1985. The $\mathrm{Si}: \mathrm{C}: \mathrm{N}$ ratio of marine diatoms. Interspecific variability and the effect of some environmental variables. Journal of Phycology 21, 347-357.

Brzezinski, M.A., Nelson, D.M., Franck, V.M., Sigmon, D.E., 2001. Silicon dynamics within an intense open-ocean diatom bloom in the Pacific sector of the Southern Ocean. Deep-Sea Research II 49, 3997-4018.

Capone, D.G., Zehr, J.P., Pearl, H.W., Berman, B., Carpenter, E.J., 1997. Trichodesmium, a globally significant marine cyanobacterium. Science 276, 1221-1229.

Capone, D.G., Subramaniam, A., Montoya, J.P., Voss, M., Humborg, C., Johansen, A.M., Siefert, R.L., Carpenter, E.J., 1998. An extensive bloom of the $\mathrm{N}_{2}$-fixing cyanobacterium Trichodesmium erythraeum in the central Arabian Sea. Marine Ecology Progress Series 172, 281-292.

Carbonell, M.C., 1985. Phytoplankton of an ice-edge bloom in the Ross Sea, with special reference to the elemental composition of Antarctic diatoms. MS thesis, Oregon State University, Corvallis, 133pp.

Carlson, C.A., Ducklow, H.W., Michaels, A.F., 1994. Annual flux of dissolved organic carbon from the Euphotic zone in the northwestern Sargasso Sea. Nature 371, 405-408.

Coale, K.H., Johnson, K.S., Fitzwater, S.E., Gordon, R.M., Tanner, S., Chavez, F.P., Ferioli, L., Sakamoto, C., Rogers, P., Millero, F., Steinberg, P., Nightingale, P., Cooper, D., Cochlan, W.P., Landry, M.R., Constantiou, J., Rollwagen, G., Trasvina, A., Kudela, R., 1996. A massive phytoplankton bloom induced by an ecosystem-scale iron fertilization experiment in the equatorial Pacific Ocean. Nature 383, 495-501.

Conkright, M.E., Levitus, S., O'Brien, T., Boyer, T.P., Stephens, C., Johnson, D., Stathoplos, L., Baranova, O., Antonov, J., Gelfeld, R., Burney, J., Rochester, J., Forgy, C., 1998. World Ocean Database 1998 CD-ROM Data Set Documentation. National Oceanographic Data Center, Silver Spring, MD.

de Baar, H.J.W., de Jong, J.T.M., Bakker, D.C.E., Löscher, B.M., Veth, C., Bathmann, U., Smetacek, V., 1995. Importance of iron for plankton blooms and carbon dioxide drawdown in the Southern Ocean. Nature 373, 412-415.

de Baar, H.J.W., de Jong, J.T.M., Nolting, R.F., Timmermans, K.R., van Leeuwe, M.A., Bathmann, U., Rutgers van der Loeff, M., Sildam, J., 1999. Low dissolved Fe and the absence of diatom blooms in remote pacific waters of the Southern Ocean. Marine Chemistry 66, 1-34.

De La Rocha, C.L., Hutchins, D.A., Brzezinski, M.A., Zhang, Y., 2000. Effects of iron and zinc deficiency on elemental composition and silica production by diatoms. Marine Ecology Progress Series 195, 71-79.

DiTullio, G.R., Hutchins, D.A., Bruland, K.W., 1993. Interaction of iron and major nutrients controls phytoplankton growth and species composition in the tropical North Pacific Ocean. Limnology and Oceanography 38, 495-508.

Doney, S.C., 1999. Major challenges confronting marine biogeochemical modeling. Global Biogeochemical Cycles 13, $705-714$. 
Doney, S.C., Glover, D.M., Najjar, R.G., 1996. A new coupled, one-dimensional biological-physical model for the upper ocean: applications to the JGOFS Bermuda Atlantic time-series study (BATS) site. Deep-Sea Research II 43, 591-624.

Doney, S.C., Large, W.G., Bryan, F.O., 1998. Surface ocean fluxes and water-mass transformation rates in the coupled NCAR climate system model. Journal of Climate 11, 1420-1441.

Doney, S.C., Yeager, S., Danabasoglu, G., Large, W., McWilliams, J.C., Submitted. Modeling oceanic interannual variability (1958-1997): Simulation design and Model-data evaluation. Journal of Physical Oceanography, submitted for publication.

Duce, R.A., 1986. The impact of atmospheric nitrogen, phosphorus, and iron species on marine biological productivity. In: Buat-Ménard, P. (Ed.), The role of air-sea exchange in geochemical cycling. D. Reidel, Dordrecht, pp. 497-529.

Duce, R.A., Tindale, N.W., 1991. Atmospheric transport of iron and its deposition in the ocean. Limnology and Oceanography 36, 1715-1726.

Duce, R.A., Liss, P.S., Atlas, E.L., Buat-Menard, P., Hicks, B.B., Miller, J.M., Prospero, J.M., Arimoto, R., Church, T.M., Ellis, W., Galloway, J.N., Hansen, L., Jickells, T.D., Knap, A.H., Reinhardt, K.H., Schneider, B., Soudine, A., Tokos, J.J., Tsunogai, S., Wollast, R., Zhou, M., 1991. The atmospheric input of trace species to the world ocean. Global Biogeochemical Cycles 5, 193-259.

Dugdale, R.C., Wilkerson, F.P., 1998. Silicate regulation of new production in the equatorial pacific upwelling. Nature 391, 270-273.

Dugdale, R.C., Wilkerson, F.P., Minas, H.J., 1995. The role of a silicate pump in driving new production. Deep-Sea Research I 42, 697-719.

Dunne, J.P., Murray, J.W., Aufdenkampe, A.K., Blain, S., Rodier, M., 1999. Silicon-nitrogen coupling in the equatorial pacific upwelling zone. Global Biogeochemical Cycles 13, 715-726.

Dupouy, C., Neveux, J., Subramaniam, A., Mulholland, M.R., Montoya, J.P., Campbell, L., Carpenter, E.J., Capone, D.G., 2000. Satellite captures Trichodesmium blooms in the southwestern tropical pacific. Eos, Transactions, American Geophysical Union 81 (2), 13-16.

Eppley, R.W., Peterson, B.J., 1979. Particulate organic matter flux and planktonic new production in the deep ocean. Nature 282, 677-680.

Falkowski, P.G., 1997. Evolution of the nitrogen cycle and its influence on the biological sequestration of $\mathrm{CO}_{2}$ in the ocean. Nature 387, 272-275.

Fung, I.Y., Meyn, S.K., Tegen, I., Doney, S.C., John, J.G., Bishop, J.K.B., 2000. Iron supply and demand in the upper ocean. Global Biogeochemical Cycles 14, 281-291.

Geider, R.J., MacIntyre, H.L., Kana, T.M., 1996. A dynamic model of photoadaptation in phytoplankton. Limnology and Oceanography 41, 1-15.

Geider, R.J., MacIntyre, H.L., Kana, T.M., 1998. A dynamic regulatory model of phytoplankton acclimation to light, nutrients, and temperature. Limnology and Oceanography 43, 679-694.

Gent, P.R., Bryan, F.O., Danabasoglu, G., Doney, S.C., Holland, W.R., Large, W.G., McWilliams, J.C., 1998. The NCAR climate system model global ocean component. Journal of Climate 11, 1287-1306.

Goldman, J.C., 1993. Potential role of large oceanic diatoms in new primary production. Deep-Sea Research I 40, $159-168$.

Gordon, R.M., Coale, K.H., Johnson, K.S., 1997. Iron distributions in the equatorial Pacific: implications for new production. Limnology and Oceanography 42, 419-431.

Gruber, N., Sarmiento, J.L., 1997. Global patterns of marine nitrogen fixation and denitrification. Global Biogeochemical Cycles 11, 235-266.

Hansell, D.A., Feely, R.A., 2000. Atmospheric intertropical convergence impacts surface ocean carbon and nitrogen biogeochemistry in the western tropical pacific. Geophysical Research Letters 27, 1013-1016.

Harrison, K.G., 2000. Role of increased marine silica input on paleo-pCO ${ }_{2}$ levels. Paleoceanography 15, 292-298.

Helbling, E.W., Villafañe, V., Holm-Hansen, O., 1991. Effect of iron on productivity and size distribution of Antarctic phytoplankton. Limnology and Oceanography 36, 1879-1885. 
Holligan, P.M., Fernández, E., Aiken, J., Balch, W.M., Boyd, P., Burkill, P.H., Finch, M., Groom, S.B., Malin, G., Muller, K., Purdie, D.A., Robinson, C., Trees, C.C., Turner, S.M., van der Wal, P., 1993. A biogeochemical study of the Coccolithophore, Emiliania Huxleyi, in the North Atlantic. Global Biogeochemical Cycles 7, 879-900.

Hutchins, D.A., Bruland, K.W., 1998. Iron-limited growth and $\mathrm{Si}: \mathrm{N}$ uptake ratios in a coastal upwelling regime. Nature 393, 564-571.

Hutchins, D.A., DiTullio, G.R., Bruland, K.W., 1993. Iron and regenerated production: evidence for biological iron recycling in two marine environments. Limnology and Oceanography 38, 1242-1255.

Hutchins, D.A., DiTullio, G.R., Zhang, Y., Bruland, K.W., 1998. An iron limitation mosaic in the California upwelling regime. Limnology and Oceanography 43, 1037-1054.

Hutchins, D.A., Witter, A.E., Butler, A., Luther III, G.W., 1999. Competition among marine phytoplankton for different chelated iron species. Nature 400, 858-861.

Iglesias-Rodriguez, M.D., Brown, C.W., Doney, S.C., Kleypas, J., Kolber, D., Kolber, Z., Hayes, P.K., Falkkowski, P.G., Representing key phytoplankton functional groups in ocean carbon cycle models: coccolithophores, submitted to Global Biogeochemical Cycles.

Jickells, T., Spokes, L., in press. Atmospheric iron inputs to the oceans. In: Turner, D., Hunter, K. (Eds.), Biogeochemistry of Iron in Seawater. Wiley, New York.

Johnson, K.S., Gordon, R.M., Coale, K.H., 1997. What controls dissolved iron concentrations in the World Ocean? Marine Chemistry 57, 137-161.

Karl, D., Letelier, R., Hebel, D., Tupas, L., Dore, J., Christian, J., Winn, C., 1995. Ecosystem changes in the North Pacific subtropical gyre attributed to the 1991-92 El Niño. Nature 388, 533-538.

Karl, D.R., Letelier, R., Tupas, L., Dore, J., Christian, J., Hebel, D., 1997. The role of nitrogen fixation in biogeochemical cycling in the subtropical North Pacific Ocean. Nature 388, 533-538.

Kumar, N., Anderson, R.F., Mortlock, R.A., Froelich, P.N., Kubik, P., Dittrich-Hannen, B., Suter, M., 1995. Increased biological productivity and export production in the glacial Southern Ocean. Nature 378, 675-680.

Kustka, A., Saludo-Wilhelmy, S., Carpenter, E.J., Capone, D.G., Raven, J., submitted. A revised iron use efficiency model of nitrogen fixation, with special reference to the marine $\mathrm{N}_{2}$ fixing cyanobacterium, Trichodesmium spp. (Cyanophyta) Journal of Phycology, submitted for publication.

Landry, M.R., Constantinou, J., Kirshtein, J., 1995. Microzooplankton grazing in the central equatorial Pacific during February and August, 1992. Deep-Sea Research II 42, 657-671.

Landry, M.R., Barber, R.T., Bidigare, R.R., Chai, F., Coale, K.H., Dam, H.G., Lewis, M.R., Lindley, S.T., McCarthy, J.J., Roman, M.R., Stoecker, D.K., Verity, P.G., White, J.R., 1997. Iron and grazing constraints on primary production in the central equatorial pacific: an EqPac synthesis. Limnology and Oceanography 42, 405-418.

Large, W.G., Danabasoglu, G., Doney, S.C., McWilliams, J.C., 1997. Sensitivity to surface forcing and boundary layer mixing in the NCAR CSM ocean model: annual-mean climatology. Journal of Physical Oceanography 27, $2418-2447$.

Laws, E.A., Falkowski, P.G., Smith Jr., W.O., Ducklow, H., McCarthy, J.J., 2000. Temperature effects on export production in the open ocean. Global Biogeochemical Cycles 14, 1231-1246.

Letelier, R.M., Karl, D.M., 1996. Role of Trichodesmium spp. in the productivity of the subtropical North Pacific Ocean. Marine Ecology Progress Series 133, 263-273.

Letelier, R.M., Karl, D.M., 1998. Trichodesmium spp. physiology and nutrient fluxes in the North Pacific subtropical gyre. Aquatic Microbial Ecology 15, 265-276.

Lessard, E.J., Murrell, M.C., 1998. Microzooplankton herbivory and phytoplankton growth in the northwestern Sargasso Sea. Aquatic Microbial Ecology 16, 173-188.

Leynaert, A., Tréguer, P., Lancelot, C., Rodier, M., 2001. Silicon limitation of biogenic silica production in the Equatorial Pacific. Deep-Sea Research I 48, 639-660.

Lipschultz, F., Owens, N.J.P., 1996. An assessment of nitrogen fixation as a source of nitrogen to the North Atlantic Ocean. Biogeochemistry 35, 261-274.

Longhurst, A.R., Bedo, A.W., Harrison, W.G., Head, E.J.H., Sameoto, D.D., 1990. Vertical flux of respiratory carbon by oceanic diel migrant biota. Deep-Sea Research I 37, 685-694. 
Löscher, B.M., de Baar, H.J.W., de Jong, J.T.M., Veth, C., Dehairs, F., 1997. The distribution of Fe in the Antarctic circumpolar current. Deep-Sea Research II 44, 143-187.

Luther III, G.W., Wu, J., 1997. What controls dissolved iron concentrations in the world ocean? - a comment. Marine Chemistry 57, 173-179.

Mahowald, N., Kohfeld, K., Hansson, M., Balkanski, Y., Harrison, S.P., Prentice, I.C., Schulz, M., Rodhe, H., 1999. Dust sources and deposition during the last glacial maximum and current climate: a comparison of model results with paleodata from ice cores and marine sediments. Journal of Geophysical Research 104, 15 895-15916.

Maldonado, M.T., Price, N.M., 1999. Utilization of iron bound to strong organic ligands by plankton communities in the subarctic pacific ocean. Deep-Sea Research II 46, 2447-2473.

Maldonado, M.T., Boyd, P.W., Harrison, P.J., Price, N.M., 1999. Co-limitation of phytoplankton growth by light and Fe during winter in the NE subarctic Pacific Ocean. Deep-Sea Research II 46, 2475-2485.

Maranger, R., Bird, D.F., Price, N.M., 1998. Iron acquisition by photosynthetic marine phytoplankton from ingested bacteria. Nature 396, 248-251.

Martin, J.H., 1990. Glacial-interglacial $\mathrm{CO}_{2}$ change: the iron hypothesis. Paleoceanography 5, 1-13.

Martin, J.H., 1992. Iron as a limiting factor in oceanic productivity. In: Falkowski, P.G., Woodhead, A.D. (Eds.), Primary Productivity and Biogeochemical Cycles in the Sea. Plenum Press, New York, pp. 123-137.

Martin, J.H., Gordon, R.M., 1988. Northeast pacific iron distributions in relation to phytoplankton productivity. Deep-Sea Research I 35, 177-196.

Martin, J.H., Gordon, R.M., Fitzwater, S.E., Broenkow, W.W., 1989. Vertex: phytoplankton/iron studies in the Gulf of Alaska. Deep-Sea Research I 36, 649-680.

Martin, J.H., Gordon, R.M., Fitzwater, S.E., 1990. Iron in Antarctic waters. Nature 345, 156-158.

Martin, J.H., Gordon, R.M., Fitzwater, S.E., 1991. The case for iron. Limnology and Oceanography 36, 1793-1802.

Martin, J.H., Fitzwater, S.E., Gordon, R.M., Hunter, C.N., Tanner, S.J., 1993. Iron, primary production and carbonnitrogen flux studies during the JGOFS North Atlantic bloom experiment. Deep-Sea Research II 40, 115-134.

McCarthy, J.J., Carpenter, E.J., 1979. Oscillatoria (Trichodesmium) Thiebautii (cyanophyta) in the central North Atlantic ocean. Journal of Phycology 15, 75-82.

McClain, C.R., Cleave, M.L., Feldman, G.C., Gregg, W.W., Hooker, S.B., Kuring, N., 1998. Science quality SeaWiFS data for global biosphere research. Sea Technology, September, 10-16.

Measures, C.I., Vink, S., 1999. Seasonal variations in the distribution of $\mathrm{Fe}$ and $\mathrm{Al}$ in the surface waters of the Arabian Sea. Deep-Sea Research II 46, 1597-1622.

Measures, C.I., Vink, S., 2001. Dissolved Fe in the upper waters of the Pacific Sector of the Southern Ocean. Deep-Sea Research II 48, 3913-3941.

Michaels, A.F., Bates, N.R., Buesseler, K.O., Carlson, C.A., Knap, A.H., 1994. Carbon-cycle imbalance in the Sargasso Sea. Nature 372, 537-540.

Milliman, J.D., 1993. Production and accumulation of calcium carbonate in the ocean: budget of a nonsteady state. Global Biogeochemical Cycles 7, 927-957.

Milliman, J.D., Troy, P.J., Balch, W.M., Adams, A.K., Li, Y.H., Mackenzie, F.T., 1999. Biologically mediated dissolution of calcium carbonate above the chemical lysocline? Deep-Sea Research I 46, 1653-1669.

Monterey, G., Levitus, S., 1997. Seasonal Variability of Mixed Layer Depth for the World Ocean. NOAA Atlas NESDIS 14, US Government Printing Office, Washington, DC,96pp.

Moore, J.K., Abbott, M.R., 2000. Chlorophyll distributions and primary production in the southern ocean. Journal of Geophysical Research 105, 28 709-28 722.

Moore, J.K., Abbott, M.R., Richman, J.G., Nelson, D.M., 2000. The southern ocean at the last glacial maximum: a strong sink for atmospheric carbon dioxide. Global Biogeochemical Cycles 14, 455-475.

Moore, J.K., Doney, S.C., Kleypas, J.A., Glover, D.M., Fung, I.Y., 2002. An intermediate complexity marine ecosystem model for the global domain. Deep-Sea Research II 49, 403-462.

Morel, F.M.M., Reinfelder, J.R., Roberts, S.B., Chamberlain, C.P., Lee, J.G., Yee, D., 1994. Zinc and carbon colimitation of marine phytoplankton. Nature 369, 740-742.

National Snow and Ice Data Center, 2000. Passive Microwave Derived Monthly Polar Sea Ice Concentration Time Series. Digital data available from nsidc@kryos.colorado.edu, Boulder, CO, NSIDC Distributed Active Archive Center, University of Colorado at Boulder. 
Nelson, D.M., Tréguer, P., 1992. Role of silicon as a limiting nutrient to Antarctic diatoms: evidence from kinetic studies in the Ross Sea ice-edge zone. Marine Ecology Progress Series 80, 255-264.

Nelson, D.M., Tréguer, P., Brzezinski, M.A., Leynaert, A., Quéguiner, B., 1995. Production and dissolution of biogenic silica in the ocean: revised global estimates, comparison with regional data and relationship to biogenic sedimentation. Global Biogeochemical Cycles 9, 359-372.

Nelson, D.M., Brzezinski, M.A., Sigmon, D.E., Frank, V.M., 2001. A seasonal progression of Si limitation in the Pacific sector of the Southern Ocean. Deep Sea Research II 49, 3973-3995.

Orcutt, K.M., Ammermann, J.W., Gunderen, K., submitted. Ectoenzyme activities associated with Trichodesmium colonies in the Sargasso Sea. Aquatic Microbial Ecology, submitted for publication.

Orcutt, K.M., Lipschultz, F., Gunderson, K., Armoto, R., Michaels, A.F., Knap, A.H., Gallon, J.R., 2001. A seasonal study of the significance of $\mathrm{N}_{2}$ fixation by Trichodesmium spp. at the Bermuda Atlantic Time-series Study (BATS) site. Deep-Sea Research II 48, 1583-1608.

Price, N.M., Ahner, B.A., Morel, F.M.M., 1994. The equatorial Pacific Ocean: grazer-controlled phytoplankton populations in an iron-limited system. Limnology and Oceanography 39, 520-534.

Raven, J.A., 1988. The iron and molybdenum use efficiencies of plant growth with different energy, carbon, and nitrogen sources. New Phytologist 109, 279-288.

Reuter, J.G., Hutchins, D.A., Smith, R.W., Unsworth, N.L., 1992. Iron nutrition of Trichodesmium. In: Carpenter, E.J., et al. (Eds.), Marine Pelagic Cyanobacteria: Trichodesmium and other Diazotrophs. Kluwer Academic Publishers, Netherlands, pp. 289-306.

Robertson, J.E., Robinson, C., Turner, D.R., Holligan, P., Watson, A.J., Boyd, P., Fernandez, E., Finch, M., 1994. The impact of a coccolithophore bloom on oceanic carbon uptake in the northeast Atlantic during summer 1991. Deep-Sea Research I 41, 297-314.

Rea, D.K., 1994. The paleoclimatic record provided by eolian deposition in the deep sea: the geologic history of wind. Reviews of Geophysics 32, 159-195.

Richardson, T.L., Cullen, J.J., Kelley, D.E., Lewis, M.R., 1998. Potential contributions of vertically migrating rhizosolenia to nutrient cycling and new production in the open ocean. Journal of Plankton Research 20, 219-241.

Rossow, W.B., Schiffer, R.A., 1991. ISCCP cloud data products. Bulletin of the American Meteorological Society 72, $2-20$.

Rue, E.L., Bruland, K.W., 1995. Complexation of iron(III) by natural organic ligands in the Central North Pacific as determined by a new competitive ligand equilibration/adsorptive cathodic stripping voltammetric method. Marine Chemistry 50, 117-138.

Rue, E.L., Bruland, K.W., 1997. The role of organic complexation on ambient iron chemistry in the equatorial Pacific Ocean and the response of a mesoscale iron addition experiment. Limnology and Oceanography 42, 901-910.

Sedwick, P.N., DiTullio, G.R., Mackey, D.J., 2000. Iron and manganese in the Ross Sea, Antarctica: seasonal iron limitation in Antarctic shelf waters. Journal of Geophysical Research 105, 11321-11336.

Sieracki, M.E., Verity, P.G., Stoecker, D.K., 1993. Plankton community response to sequential silicate and nitrate depletion during the 1989 North Atlantic spring bloom. Deep-Sea Research II 40, 213-225.

Strom, S.L., Welschmeyer, N.A., 1991. Pigment-specific rates of phytoplankton growth and microzooplankton grazing in the open Subarctic Pacific Ocean. Limnology and Oceanography 36, 50-63.

Sunda, W.G., 1997. Control of dissolved iron concentrations in the world ocean: a comment. Marine Chemistry 57, $169-172$.

Sunda, W.G., Huntsman, S.A., 1995. Iron uptake and growth limitation in oceanic and coastal phytoplankton. Marine Chemistry 50, 189-206.

Sunda, W.G., Huntsman, S.A., 1997. Interrelated influence of iron, light and cell size on marine phytoplankton growth. Nature 390, 389-392.

Sunda, W.G., Swift, D.G., Huntsman, S.A., 1991. Low iron requirement for growth in oceanic phytoplankton. Nature $351,55-57$.

Takeda, S., 1998. Influence of iron availability on nutrient consumption ratio of diatoms in oceanic waters. Nature 393, 774-777.

Takeda, S., Obata, H., 1995. Response of equatorial pacific phytoplankton to subnanomolar Fe enrichment. Marine Chemistry 50, 219-227. 
Takeda, S., Kamatani, A., Kawanobe, K., 1995. Effects of nitrogen and iron enrichments on phytoplankton communities in the northwestern Indian Ocean. Marine Chemistry 50, 229-241.

Tegen, I., Fung, I.Y., 1994. Modeling of mineral dust in the atmosphere: sources, transport, and optical thickness. Journal of Geophysical Research 99, 22 897-22914.

Tegen, I., Fung, I.Y., 1995. Contribution to the atmospheric mineral aerosol load from land surface modifications. Journal of Geophysical Research 100, 18707-18726.

Tortell, P.D., Maldonado, M.T., Price, N.M., 1996. The role of heterotropic bacteria in iron-limited ocean ecosystems. Nature 383, 330-332.

Tréguer, P., Lindner, L., van Bennekom, A.J., Leynaert, A., Panouse, M., Jacques, G., 1991. Production of biogenic silica in the Weddell-Scotia Seas measured with ${ }^{32}$ Si. Limnology and Oceanography 36, 1217-1227.

Tréguer, P., Nelson, D.M., Van Bennekom, A.J., DeMaster, D.J., Leynaert, A., Quéguiner, B., 1995. The silica balance in the world ocean: a reestimate. Science 268, 375-379.

Villareal, T.A., Altabet, M.A., Culver-Rymsa, K., 1993. Nitrogen transport by migrating diatom mats in the North Pacific Ocean. Nature 363, 709-712.

Villareal, T.A., Woods, S., Moore, J.K., Culver-Rymsza, K., 1996. Vertical migration of Rhizosolenia mats and their significance to $\mathrm{NO}_{3}$ fluxes in the central north pacific gyre. Journal of Plankton Research 18, 1103-1121.

Villareal, T.A., Pilskaln, C., Brzezinski, M., Lipschultz, F., Dennett, M., Gardner, G.B., 1999. Upward transport of oceanic nitrate by migrating diatom mats. Nature 397, 423-425.

Wells, M.L., Price, N.M., Bruland, K.W., 1995. Iron chemistry in seawater and its relationship to phytoplankton: a workshop report. Marine Chemistry 48, 157-182.

Wu, J., Luther III, G.W., 1994. Size-fractionated iron concentrations in the water column of the western North Atlantic Ocean. Limnology and Oceanography 39, 1119-1129.

Wu, J., Luther III, G.W., 1996. Spatial and temporal distributions of iron in the surface water of the northwestern Atlantic Ocean. Geochimica et Cosmochimca Acta 60, 2729-2741.

Wu, J., Sunda, W., Boyle, E.A., Karl, D.M., 2000. Phosphate depletion in the western North Atlantic. Science 289, $759-762$.

Yamanaka, Y., Tajika, E., 1996. The role of the vertical fluxes of particulate organic matter and calcite in the oceanic carbon cycle: studies using an ocean biogeochemical general circulation model. Global Biogeochemical Cycles 10, 361-382.

Zhu, X.R., Prospero, J.M., Millero, F.J., 1997. Diel variability of soluble Fe(II) and soluble total Fe in North African dust in the trade winds at Barbados. Journal of Geophysical Research 102, 21 297-21 305. 